\title{
Updating Frasnian miospore zonation from the Boulonnais (Northern France) and comparison with new data from the Upper Palaeozoic cover on the Brabant Massif (Western Belgium)
}

\author{
Maurice STREEL ${ }^{1 *}$, Frédéric BOULVAIN ${ }^{2}$, Michiel DUSAR $^{3}$, StANiSlas LOBOZIAK $^{4}$ \& PhilipPe STEEMANS 5 \\ ${ }^{1}$ Department of Geology, Bât B-18, University of Liège, B-4000 Liège, Belgium. \\ ${ }^{2}$ Sedimentary Petrology, Bât B-20, University of Liège, B-4000 Liège, Belgium. \\ ${ }^{3}$ Royal Belgian Institute of Natural Sciences-Geological Survey of Belgium, B-1000 Brussels, Belgium. \\ ${ }^{4}$ Deceased. \\ ${ }^{5}$ EDDy Lab/Palaeopalynology, Bât B-18, University of Liège, B-4000 Liège, Belgium. \\ * corresponding author: maurice.streel@uliege.be.
}

\begin{abstract}
Accurate palyno-analysis by S. Loboziak (from 1980 to 1983) of 28 samples from the Upper Givetian to the Middle Frasnian Blacourt, Beaulieu and Ferques Formations and of 44 samples of the Upper Frasnian to the Lower Famennian Hydrequent Formation are re-evaluated. Chelinospora concinna, Verrucosisporites bulliferus, Cirratriradites jekhowskyi, Lophozonotriletes media first occurrences are major criteria for Lower and Middle Frasnian, well calibrated by conodonts. Cymbosporites acanthaceus, Rugospora bricei, Grandispora gracilis, Diducites plicabilis, Corbulispora vimineus first occurrences allow to subdivide the Upper Frasnian where conodonts are poorly present. Samarisporites triangulatus versus Auroraspora pseudocrista taxonomy and stratigraphic significance are discussed.

The reconnaissance borehole Nieuwkerke-De Seule (95W152), near the limit of the Upper Palaeozoic subcrop on the Brabant Massif (West Flanders, Belgium, $75 \mathrm{~km}$ east of the Boulonnais), which has intersected conodont-dated Givetian/Frasnian boundary at the transition between the Bois de Bordeaux and Bovesse Formations, contained poorly preserved miospores attributed to the triangulatus-concinna (TCo) Oppel Zones. In the nearby Nieuwkerke-Noordhoek borehole (95W153), strata also assigned to the Bovesse Formation yielded better preserved miospores which demonstrate a close succession of triangulatus-concinna (TCo) and bulliferus-jekhowskyi (BJ) Oppel Zones at the transition Lower-Middle Frasnian, also known in the Beaulieu Formation in the Boulonnais.

Samples from the Heuvelland groundwater monitoring well (95W175), $10 \mathrm{~km}$ north of Nieuwkerke, contain the briceiacanthaceus (BA) Oppel Zone suggesting a late Frasnian age, also known in the Hydrequent Formation in the Boulonnais area and in the Booischot Formation in the Booischot borehole (59E146) from the Campine Basin (Belgium).

International correlation using Frasnian miospore zonation is attempted between the Pripyat Depression in Belarus, the TimanPechora province in Russia and North-West China.
\end{abstract}

KEYWORDS: biostratigraphy, Oppel Zones, Boulonnais, Flanders, Russia, China.

\section{Introduction}

Former accurate palyno-analysis from the Upper Givetian to the Lower Famennian in the Boulonnais (Northern France), made some forty years ago, had to be re-evaluated. Consequently, stratigraphic correlations, across the French-Belgium Boundary, between the Boulonnais and boreholes in West and East Flanders have to be revised. Some international correlations with Central and Eastern Europe and North-West China will also be made possible.

\subsection{History}

Frasnian miospores from the Boulonnais (Northern France) were first described and illustrated from one sample collected in the Beaulieu Formation believed to belong to the Lower Frasnian (Taugourdeau-Lantz, 1960). Most taxa were tentatively identified by comparison with the rich Upper Devonian miospore drawings from the Russian Platform (Naumova, 1953). Several species were updated and re-illustrated in further papers (Taugourdeau-Lantz, 1967a, b), a first palynostratigraphic chart covering the whole Frasnian being given in Taugourdeau-Lantz (1967a). The stratigraphic chart, illustration and description of miospores were again updated (TaugourdeauLantz, 1971).

A new section showing in succession the Blacourt Formation and the Beaulieu Formation was then made available in the railway track Caffiers-Ferques allowing, among other fossils, ten conodont faunas to be identified (Brice et al., 1979). These new detailed stratigraphic data have encouraged us to restudy the miospores produced in three papers concerning respectively the Givetian-Lower Frasnian (Loboziak \& Streel, 1980) and the Middle-Upper Frasnian to Lower Famennian (Loboziak \& Streel, 1981; Loboziak et al., 1983). All taxa received an identification number (from 1 to 79 , see Table 1) reused in a next paper (Loboziak \& Streel, 1988) establishing a succession of four formal Oppel Zones: Samarisporites triangulatus-Rhabdosporites langi (TLa) renamed (Streel et al., 1987), S. triangulatus-Ancyrospora ancyrea ancyrea (TA), S. triangulatus-Chelinospora concinna (TCo), Verrucosisporites bulliferus-Cirratriradites jekhowskyi (BJ), V. bulliferusLophozonotriletes media (BM) and two informal Zones (IV and $\mathrm{V})$, that were not defined in that paper. These two unformal zones were characterised and subdivided by Streel (2009) as Rugospora bricei-Cymbosporites acanthaceus (BA) and Knoxisporites dedaleus-Diducites versabilis (DV) Oppel Zones.

The former TLa Zone, now renamed TA Zone, is typified by the composition of sample G-02 at the base of the Blacourt Formation in the Griset quarry; the TCo Zone is typified by the composition of sample $\mathrm{H} 26$ in the upper part of the same formation in the Ferques railroad trench; the BJ Zone is typified by the composition of sample sequence Q52 to Q56 in the Beaulieu Formation in the Ferques railroad trench; the BM Zone is typified by the composition of samples VW5 and VW8 in the Ferques Formation in the Bois quarry (Loboziak \& Streel, 1981). The BA Zone, mainly studied in the $23 \mathrm{~m}$ of shales above the dolomitic bed (Loboziak et al., 1983, fig. 1) in the Hydrequent Formation in the "Briqueterie de Beaulieu" quarry, is more complex, requiring probably several characteristic samples to typify the subdivisions A to E (Fig. 1). The base of the DV Zone in the same quarry, could be typified by sample 109 (this paper).

\subsection{Correlation with other microfossils}

The base of TA Zone probably occurs in or below the conodont Middle varcus Zone (FIV on Fig. 1), the base of the TCo Zone ranging from the conodont (FV) Upper varcus to the Lower asymmetricus Zone (Bultynck in Streel et al., 1987). BJ and BM 
Ste GODELEINE

$$
\begin{aligned}
& z \\
& \varangle \\
& z \\
& z \\
& z \\
& w \\
& \Sigma \\
& < \\
& 4 \\
& 5 \\
& -
\end{aligned}
$$

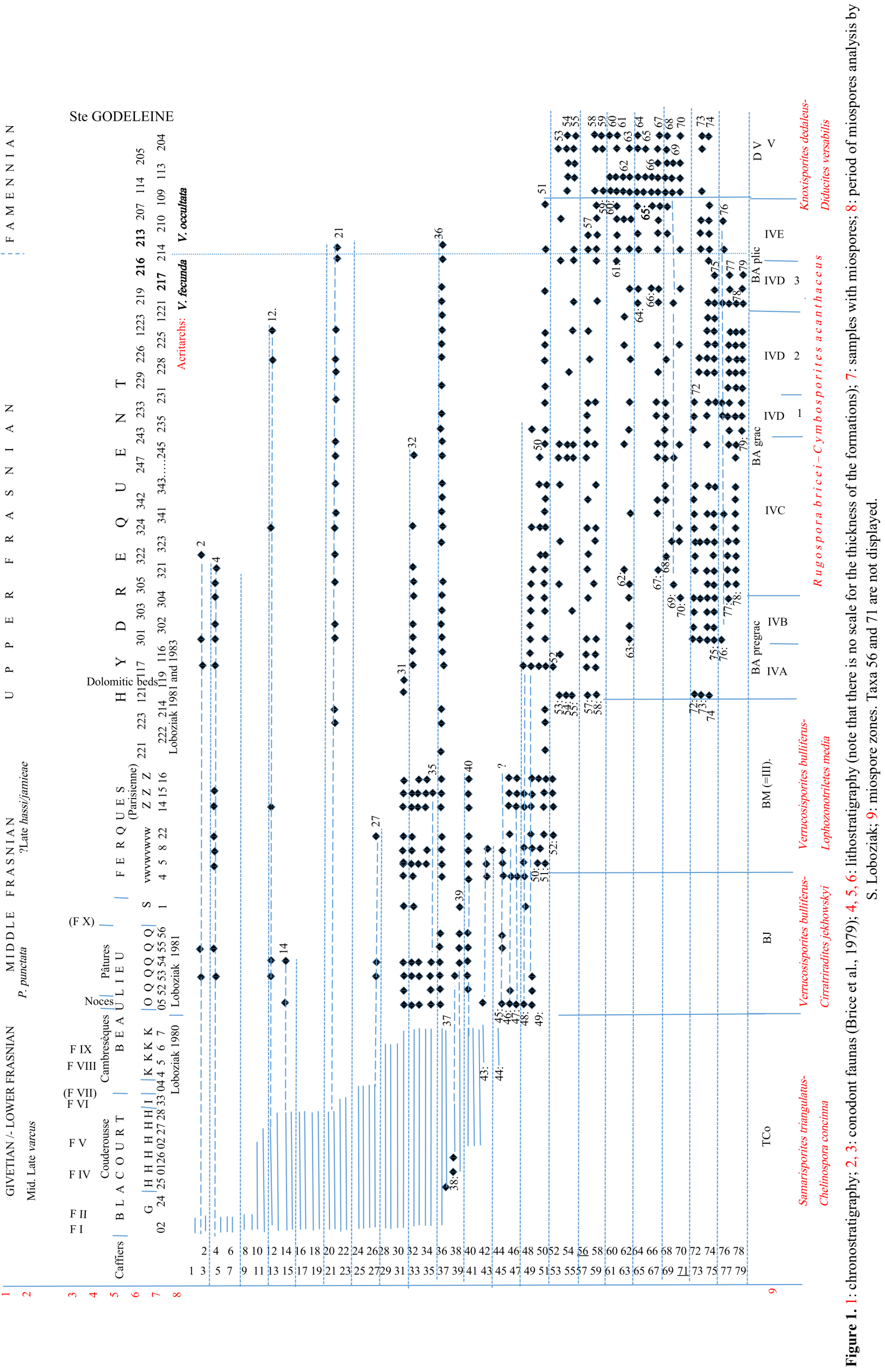




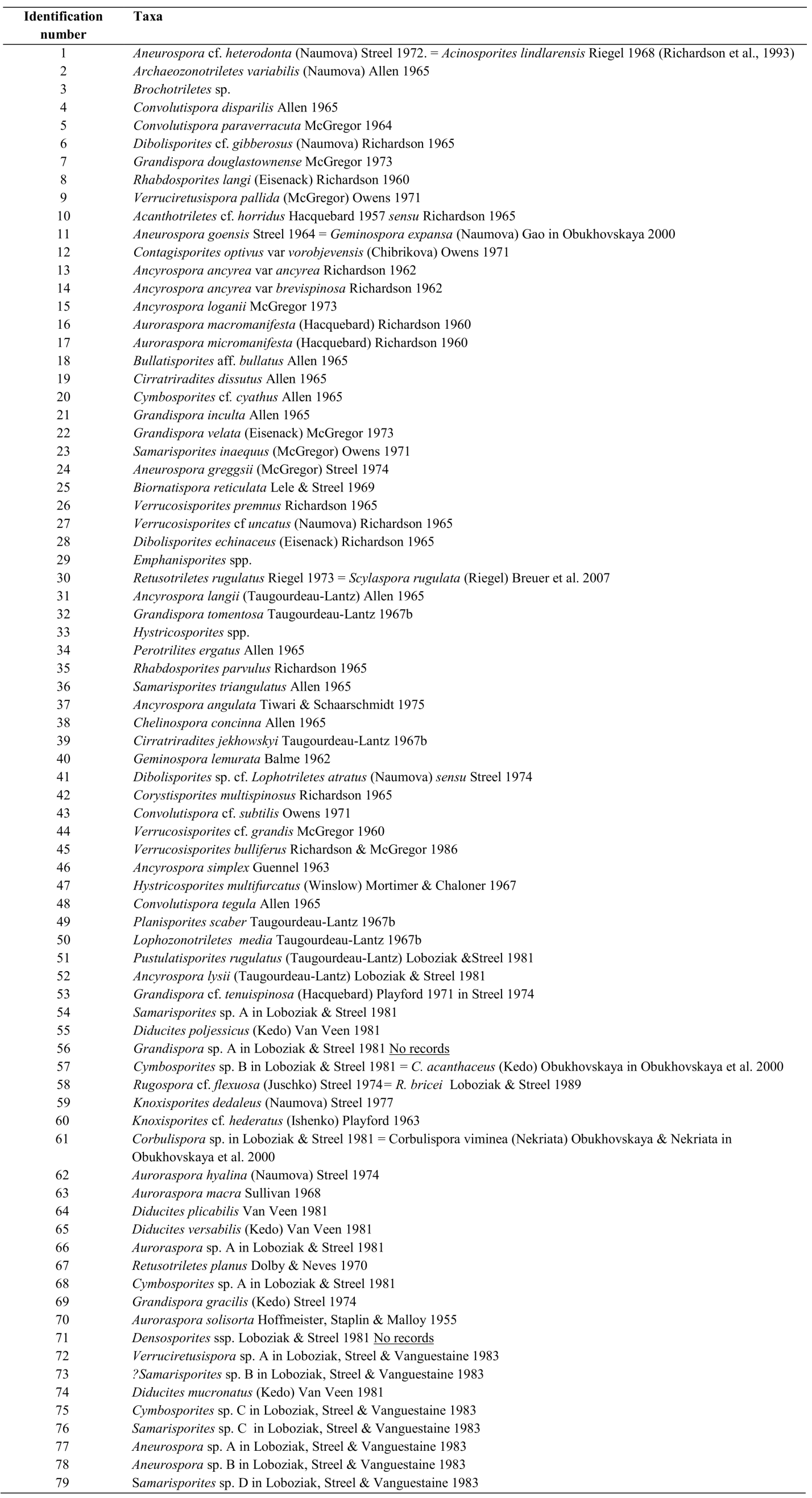

Table 1. Identification numbers of taxa recorded on Figure 1, sorted by number. Taxa are sorted by names in Appendix. 
Zones range from the conodont Lower asymmetricus Zone to as far as the conodont Ancyrognathus triangularis Zone (Brice et al., 1981).

We had attempted to provide a stratigraphic control of the Frasnian/Famennian Boundary (conodonts being poorly present in the Upper Frasnian of the Boulonnais), using acritarchs "dated" by conodonts in the type region from the Ardenne (Vanguestaine, 1986; Martin, 1993; Streel et al., 2000a). The conclusion was that the higher part of the BA Oppel Zone (BA plic Subzone, starting with the first occurrence of Diducites plicabilis in Streel, 2009) ranges from the conodont upper Palmatolepis gigas Zone to the upper Palmatolepis triangularis Zone and contains therefore the base of the Famennian Stage (Ziegler \& Sandberg, 1990).

The acritarch Visbysphaera (?) fecunda (Vf) Zone occurs in samples 217-216 of the Upper Frasnian Hydrequent Formation (Loboziak et al., 1983). The Famennian acritarch Villocapsula globosa $(\mathrm{Vg})$ Zone is not recorded in that section. If one accepts the synonymy (Vanguestaine et al., 1983) of Herkomorphytae sp. A and V.? occultata, as a good marker for the earliest Famennian in Belgium (Martin, 1993), then sample 213 of the Hydrequent Formation might be Famennian. A Frasnian/ Famennian Boundary drawn between samples 216 and 213 would match the top of several miospore species recorded in the Upper Frasnian Hydrequent Formation, i.e. Cymbosporites sp. C (75), Aneurospora sp. A (77), A. sp. B (78) and Samarisporites sp. D (79), illustrated and briefly described by Loboziak et al. (1983).

\subsection{Comments on the first occurrence (FOB) of main taxa}

Most of these papers show the range of each taxon by a line joining the first and last occurrences. This failed in not showing the quantity of data these ranges were built upon and did not enable us to evaluate the likelihood of the "presence" criterion. Figure 1 shows (according to data still available and unmodified), the presence of the selected taxa in each sample (28 samples of the Upper Givetian to the Middle Frasnian Blacourt, Beaulieu and Ferques Formations and 44 samples of the Upper Frasnian to the Lower Famennian Hydrequent Formation, all slides scanned by Stanislas Loboziak at Lille. The corresponding slides have not been revised for the present paper). One can observe then that $C$. concinna (38), V. bulliferus (45), C. jekhowskyi (39), L. media (50) first occurrences are major criteria for the Lower and Middle Frasnian, and that $C$. acanthaceus (57), R. bricei (58), G. gracilis (69), D. plicabilis (64) first occurrences allow the subdivision of the Upper Frasnian.

It might seem surprising that Samarisporites triangulatus Allen 1965 (syn.: S. euglyphus Taugourdeau-Lantz, 1967b, Cristatisporites triangulatus (Allen) McGregor \& Camfield, 1982), the eponym species of TA and TCo Oppel Zones, is not retained among the taxa listed here above. Its first occurrence is indeed controversial (Richardson \& McGregor, 1986, fig. 6; Streel, 2009, fig. 3). It might be, in part, the result of differences of palynologist acceptation of the degree of the equatorial flange reaching its maximum width radially even if it is hardly perceptible in the inter-radial regions (Allen, 1965, p. 706). Compare, for instance, Allen (1965) plate 99, Richardson \& McGregor (1986) plate 15, Loboziak et al. (1991) plate 2. It might also be that Geminospora lemurata (40) was not recognised in the few samples studied in the Blacourt Formation (Loboziak \& Streel, 1980, fig. 1) or maybe confused with Aneurospora greggsii (24) (see Streel \& Loboziak, 1987, p. 100) showing why Geminospora lemurata is recorded as being older than Samarisporites triangulatus in the Eifel (Loboziak et al., 1991) as in Canada and European Russia according to Richardson \& McGregor (1986).
The stratigraphic range of $S$. triangulatus is also questionable. According to Richardson \& McGregor (1986), it occurs in their optivus-triangulatus and ovalis-bulliferus assemblage Zones corresponding to the TA, TCo, BJ, BM and the lower part of BA Oppel Zones. Allen (1982, figs 2 and 3) has recorded many occurrences of this species and possible synonyms in the Northern hemisphere and suggests they range from Upper Givetian to Middle Frasnian.

However, in the Boulonnais, we had noted S. triangulatus as high as the top of the Frasnian.

Allen (1982) explains that its stratigraphic value is enhanced by the fact that the characteristic zona with a maximum width radially, can usually be identified even in poorly preserved specimens. It should be noted that such poorly preserved specimens might as well correspond to Auroraspora pseudocrista Ahmed 1980 ranging from the uppermost Frasnian into the Famennian and which often demonstrates one or more maximum width radially.

\section{The reconnaissance boreholes Nieuwkerke-De Seule (95W152, renamed 110W7) and Nieuwkerke- Noordhoek (95W153)}

These partly cored boreholes were drilled near the limit of the Upper Palaeozoic subcrop on the Brabant Massif (West Flanders, Belgium, $75 \mathrm{~km}$ east of the Boulonnais) (Figs 2 and 3). They are north of the Brabant Parautochthon, and within the Upper Palaeozoic cover of the Brabant Massif unaffected by the Variscan orogeny (Belanger et al., 2012). All facies indications and correlations with the Tournai, Vieux-Leuze and Annapes boreholes suggest a correlation to the lower part of the Bovesse Formation (or Beaulieu Formation in the Boulonnais) of the Frasnian strata in the Nieuwkerke boreholes (Coen-Aubert et al., 1980; Legrand, 1981; Dusar \& Loy, 1986).

Nieuwkerke-De Seule (95W152) which has penetrated conodont-dated Givetian/Frasnian boundary at the transition between the Mazy Member and the Bovesse Formation (Fig. 4), contained poorly preserved miospores attributed to the Samarisporites triangulatus-Chelinospora concinna (TCo) Oppel Zone (Tourneur et al., 1989). They are listed on Table 2.

Nieuwkerke-Noordhoek (95W153) provided three samples from the Bovesse Formation with rather well preserved miospores listed also on Table 2, suggesting proximity to the Lower/Middle Frasnian boundary.

The youngest sample $(219 \mathrm{~m})$ contains Cirratriradites jekhowskyi (39) with Chelinospora concinna (38), both taxa coexisting in the lower part of the Verrucosisporites bulliferusCirratriradites jekhowskyi (BJ) Oppel Zone.

In the sample at $221.5 \mathrm{~m}$, Retusotriletes rugulatus (30) and Verrucosisporites bulliferus (45) suggests a close proximity to the top of the Samarisporites triangulatus-Chelinospora concinna (TCo) Oppel Zone and the base of the Verrucosisporites bulliferus-Cirratriradites jekhowskyi (BJ) Oppel Zone.

In the sample $223.7 \mathrm{~m}$, Grandispora velata (22) and Corystisporites multifurcatus (42) belong to the Samarisporites triangulatus-Chelinospora concinna (TCo) Oppel Zone.

\section{The Heuvelland groundwater monitoring well (95W175), in Westouter, $10 \mathrm{~km}$ north of Nieuwkerke}

This well has also penetrated Frasnian shales covering the Brabant Massif, albeit in a north dipping position resulting in the subcrop of younger strata. One cuttings sample from the interval 260.00-262.00 m, assigned to the Franc-Waret Formation, contains the taxa recorded on Table 3.

Diducites plicabilis (64) and Grandispora gracilis (69) belong to the upper part (BA plic) of the Oppel Zone BA. 


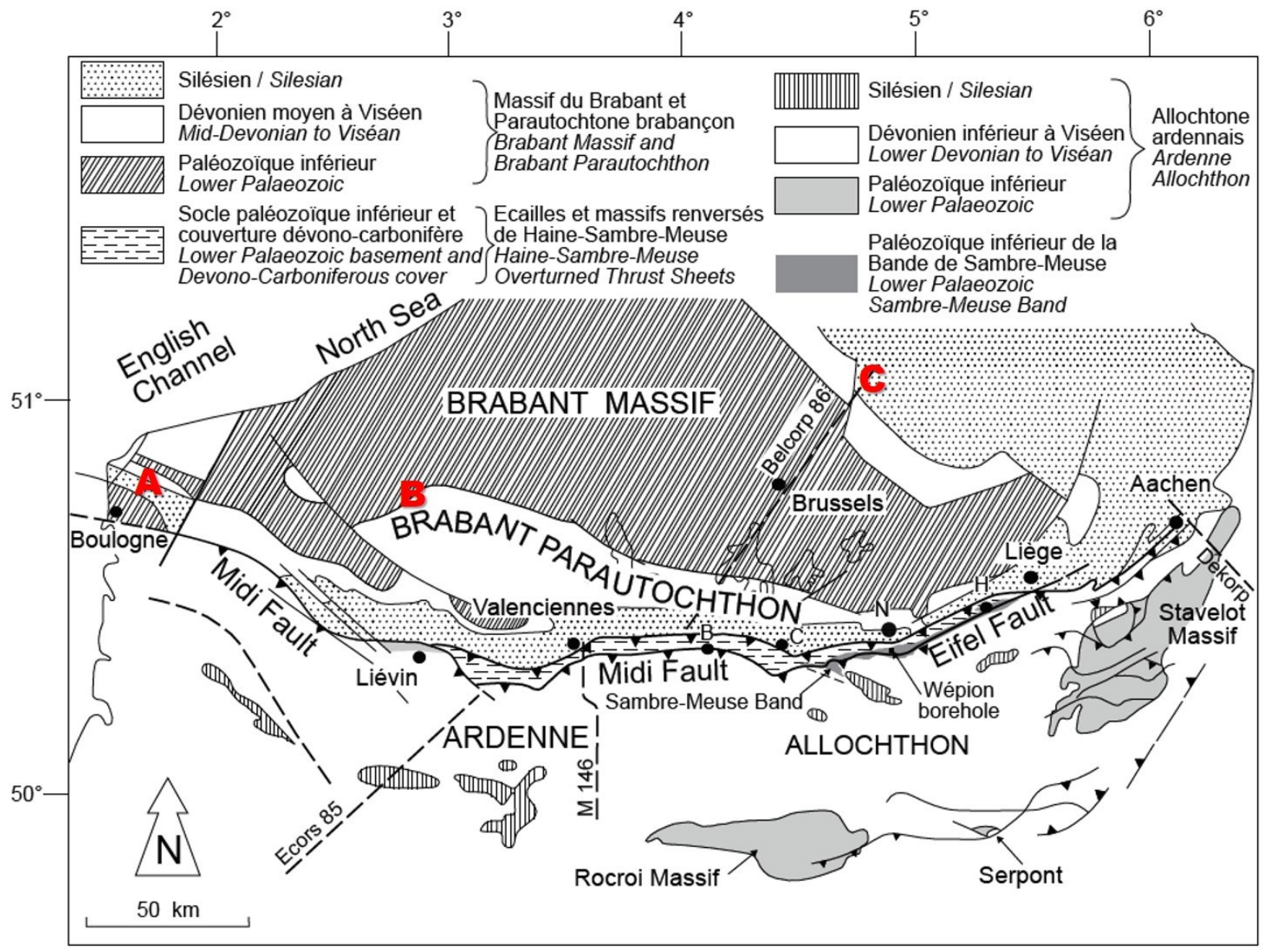

Figure 2. Location of studied boreholes and sections on a tectono-stratigraphic map showing their position in the Devonian cover sequence on the Lower Palaeozoic Brabant Massif (reprinted from Belanger et al., 2012, with permission of Geologica Belgica). A: Ferques section in the Palaeozoic core of the Boulonnais; B: Nieuwkerke boreholes on the margin of the Brabant Parautochthon south of the Brabant Massif; C: Booischot borehole in Devonian half-graben on the margin of the Variscan Campine basin north of the Brabant Massif.

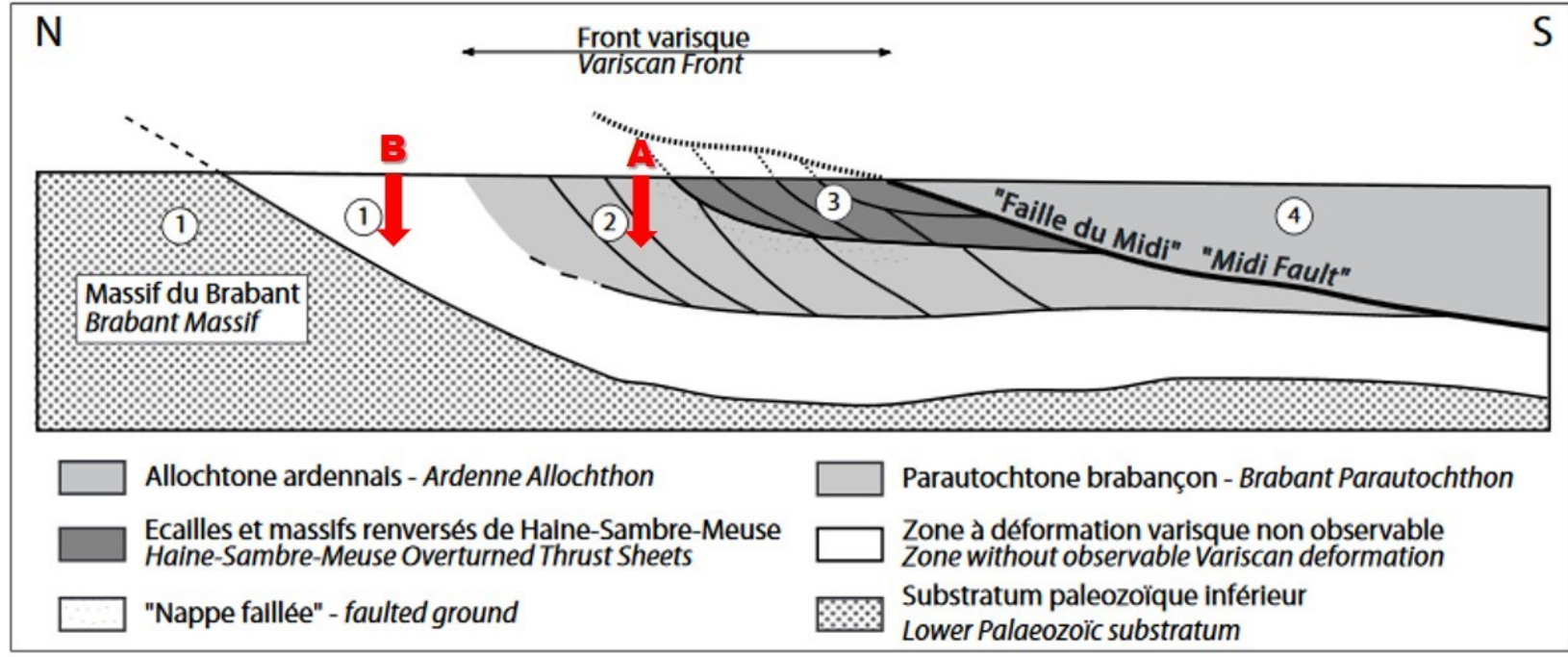

Figure 3. Schematic N-S profile between Brabant Massif and the Variscan Front (reprinted from Belanger et al., 2012, with permission of Geologica Belgica). Ferques section (A on Fig. 2) corresponds to the deformed zone 2; the Nieuwkerke boreholes (B on Fig. 2) are located in the nearly undeformed northern margin of the Brabant Parautochthon at number 1; Booischot borehole (C on Fig. 2) is located north of the Brabant Massif outside this scheme but in an approximately symmetrical position to the undeformed zone 1 of the Brabant Parautochthon. 
Table 2. Main taxa recorded in the boreholes Nieuwkerke-De Seule (95W152) and Nieuwkerke-Noordhoek (95W153). A: Identification numbers of taxa, B: List of taxa. C: Taxa recorded in Nieuwkerke (95W152) after Tourneur et al. (1989). D, E, F: Taxa recorded in the present paper in Nieuwkerke-Noordhoek (95W153): D $=223.7 \mathrm{~m}, \mathrm{E}=$ $221.5 \mathrm{~m}, \mathrm{~F}=219 \mathrm{~m}$, this paper. FOB key species presences are underlined.

\begin{tabular}{|c|c|c|c|c|c|}
\hline $\mathbf{A}$ & B & $\mathbf{C}$ & D & $\mathbf{E}$ & $\mathbf{F}$ \\
\hline 31 & Ancyrospora langii & $\mathrm{X}$ & & & \\
\hline 37 & Ancyrospora angulata & & $\mathrm{X}$ & & $\mathrm{X}$ \\
\hline 13 & Ancyrospora ancyrea ancyrea & $\mathrm{X}$ & & & \\
\hline \multirow[t]{2}{*}{24} & Aneurospora greggsii & & $\mathrm{X}$ & $\mathrm{X}$ & $\mathrm{X}$ \\
\hline & Auroraspora aff. pseudocrista & & $X$ & & \\
\hline 38 & Chelinospora concinna & & & & $\underline{\mathbf{X}}$ \\
\hline 39 & Cirratriradites jekhowskyi & & & & $\underline{\mathbf{X}}$ \\
\hline 42 & Corystisporites multispinosus & $\mathrm{X}$ & $\underline{\mathbf{X}}$ & & \\
\hline 6 & Dibolisporites cf. gibberosus & $X$ & & & \\
\hline 28 & Dibolisporites echinaceus & & & & $\mathrm{X}$ \\
\hline 29 & Emphanisporites spp & & & & $\mathrm{X}$ \\
\hline 40 & Geminospora lemurata & $\mathrm{X}$ & $\mathrm{X}$ & $\mathrm{X}$ & $\mathrm{X}$ \\
\hline 22 & Grandispora velata & & $\underline{X}$ & & \\
\hline 21 & Grandispora inculta & & $\mathrm{X}$ & & \\
\hline 33 & Hystricosporites spp. & $\mathrm{X}$ & $\mathrm{X}$ & $\mathrm{X}$ & \\
\hline 34 & Perotrilites ergatus & $\mathrm{X}$ & & & \\
\hline \multirow[t]{2}{*}{30} & Scylaspora rugulata & & & $\underline{\mathbf{X}}$ & \\
\hline & Retusotriletes confossus & & $\mathrm{X}$ & & \\
\hline 35 & Rhabdosporites parvulus & $\mathrm{X}$ & & & \\
\hline \multirow[t]{2}{*}{36} & Samarisporites triangulatus & $\mathrm{X}$ & $X$ & & \\
\hline & Samarisporites sp. E & & $\mathrm{X}$ & & \\
\hline \multirow[t]{2}{*}{45} & Verruosisporites bulliferus & \multirow{2}{*}{\multicolumn{2}{|c|}{ TCo }} & $\mathrm{X}$ & \\
\hline & & & & ?BJ & BJ \\
\hline
\end{tabular}

Table 3. Miospores recorded in the Heuvelland groundwater monitoring well (95W175).

\begin{tabular}{l} 
Miospores \\
\hline (14) Ancyrospora ancyrea var. brevispinosa Richardson 1962 \\
(31) cf. Ancyrospora langii (Taugourdeau-Lantz) Allen 1965 \\
(24) Aneurospora greggsii (McGregor) Streel 1974 \\
aff. Archaeoperisaccus sp. \\
Auroraspora pseudocrista Ahmed 1980 \\
(42) Corystisporites multispinosus Richardson 1965 \\
(64) Diducites plicabilis Van Veen 1981 \\
(29) Emphanisporites spp. \\
(69) Grandispora gracilis (Kedo) Streel 1974 \\
(33) Hystricosporites spp. \\
Pavonisporites costulatus (Taugourdeau-Lantz) Taugourdeau-Lantz 1971 \\
cf. Lophozonotriletes lebedianensis Naumova 1953 \\
cf. Retusotriletes crassus Clayton et al. 1980 \\
(36) Samarisporites triangulatus Allen 1965 \\
Samarisporites sp. cf. Acanthotriletes hirtus Naumova 1953 \\
(79) Samarisporites sp. D in Loboziak, Streel \& Vanguestaine 1983 \\
cf. Teichertospora torquata (Higgs) McGregor \& Playford 1990 \\
\hline
\end{tabular}

Samarisporites sp. E and Pavonisporites costulatus (Taugourdeau-Lantz) Taugourdeau-Lantz, 1971 are known in the Mid-Late Frasnian from the Booischot borehole from the Brabant Massif (Streel \& Loboziak, 1987). Pavonisporites costulatus (Taugourdeau-Lantz) Taugourdeau-Lantz, 1971 was originally recorded as Lagenoisporites costulatus by Taugourdeau-Lantz (1960) in the Middle Frasnian in the Boulonnais Region.

Auroraspora pseudocrista Ahmed 1980, Teichertospora torquata (Higgs) McGregor \& Playford 1990 and Lophozonotriletes lebedianensis Naumova 1953 belong to the torquata-gracilis assemblage Zone of Richardson \& McGregor 1986, ranging from the uppermost Frasnian up to the Famennian.
In conclusion the sample contains the bricei-acanthaceus (BA) Oppel Zone suggesting an Upper Frasnian age, also known in the Hydrequent Formation in the Boulonnais (France) and in the Booischot Formation in the Booischot borehole (59E146) from the Campine Basin (Belgium) (see Coen-Aubert, 2014).

\section{The Booischot borehole (59E146) from the Campine Basin (Belgium)}

The Booischot geological reconnaissance borehole (59E146), drilled in the Campine Basin, north of the Brabant Massif (Figs 2 and 4), encountered at the base of Upper Palaeozoic a thick sequence of red and green conglomerates, assigned to the Booischot Formation (Lagrou \& Coen-Aubert, 2017). The upper part of the Booischot Formation had been investigated by Streel (1965) and Streel \& Loboziak (1987). Between 1002 and 994.5 $\mathrm{m}$, the Verrucosisporites bulliferus-Lophozonotriletes media (BM) Oppel Zone recognised by Streel \& Loboziak (1987) is correlated in the Boulonnais, with the conodont zones occurring between the Middle Polygnathus asymmetricus and Ancyrognathus triangularis Zones. Higher in the borehole, Streel \& Loboziak (1987) identified between $940 \mathrm{~m}$ and $900.5 \mathrm{~m}$ the miospore interval Zones IV A, C and E present in the upper part of the Hydrequent Formation from the Boulonnais. Their miospore zonation as well as the distribution of characteristic miospores and acritarchs have been reviewed by Streel et al. (2000a, p. 131, fig. 13). In this paper, the authors correlated the miospore Zones IV B, C and partly D with the Upper Palmatolepis rhenana conodont Zone (see Coen-Aubert, 2014; Lagrou \& Coen-Aubert, 2017). Streel (2009) had renamed the IV Regional Zone as the Rugospora briceiCymbosporites acanthaceus (BA) Oppel Zone and the V Regional Zone as the Knoxisporites dedaleus-Diducites versabilis (DV) Oppel Zone.

\section{Nomenclatural notice}

Several species of Samarisporites first occurring in the BA Zone were illustrated but left in open nomenclature by Loboziak \& Streel (1981), Loboziak et al. (1983) and Streel \& Loboziak (1987). The opportunity is now taken to regularise their status.

Samarisporites sp. A (54) in Loboziak \& Streel, 1981, plate II: 7,8 .

1965. "Gen. nov." in Streel 1965, plate 1: 4-6.

1974. Samarisporites sp. cf. Hymenozonotriletes acanthyrugosus Chibrikova 1959 in Becker et al. 1974, pl. 18: 8.

1987. Samarisporites sp. A in Streel \& Loboziak 1987, plate 1: 7.

Thick, often dark, spherical central body and thin narrow equatorial wing, sometimes slightly expanding in front of the trilete rays. Ornaments are mainly composed, on the distal and equatorial surfaces, of narrow spines, 2-3 $\mu \mathrm{m}$ high. Comparable with Samarisporites sp. 2 in Breuer \& Steemans (2013), which differs in being significantly bigger.

?Samarisporites sp. B (73) in Loboziak, Streel \& Vanguestaine 1983, plate 1:11.

Rounded central body and a reticulate ornamentation with a broad mesh (fields are $10 \mu \mathrm{m}$ in diameter) and high $(2-5 \mu \mathrm{m}$ high) diaphanous muri which might be confused with the equatorial thin membrane and the high lips of the trilete mark. The generic identification remains doubtful.

Samarisporites sp. C (76) in Loboziak, Streel \& Vanguestaine 1983, plate 2: 4-6.

1989. Cf. also Samarisporites triangulatus in Loboziak \& Streel 1989, plate IV: 6-8.

Rounded central body and equatorial wing reaching up to 


\section{BOULONNAIS}

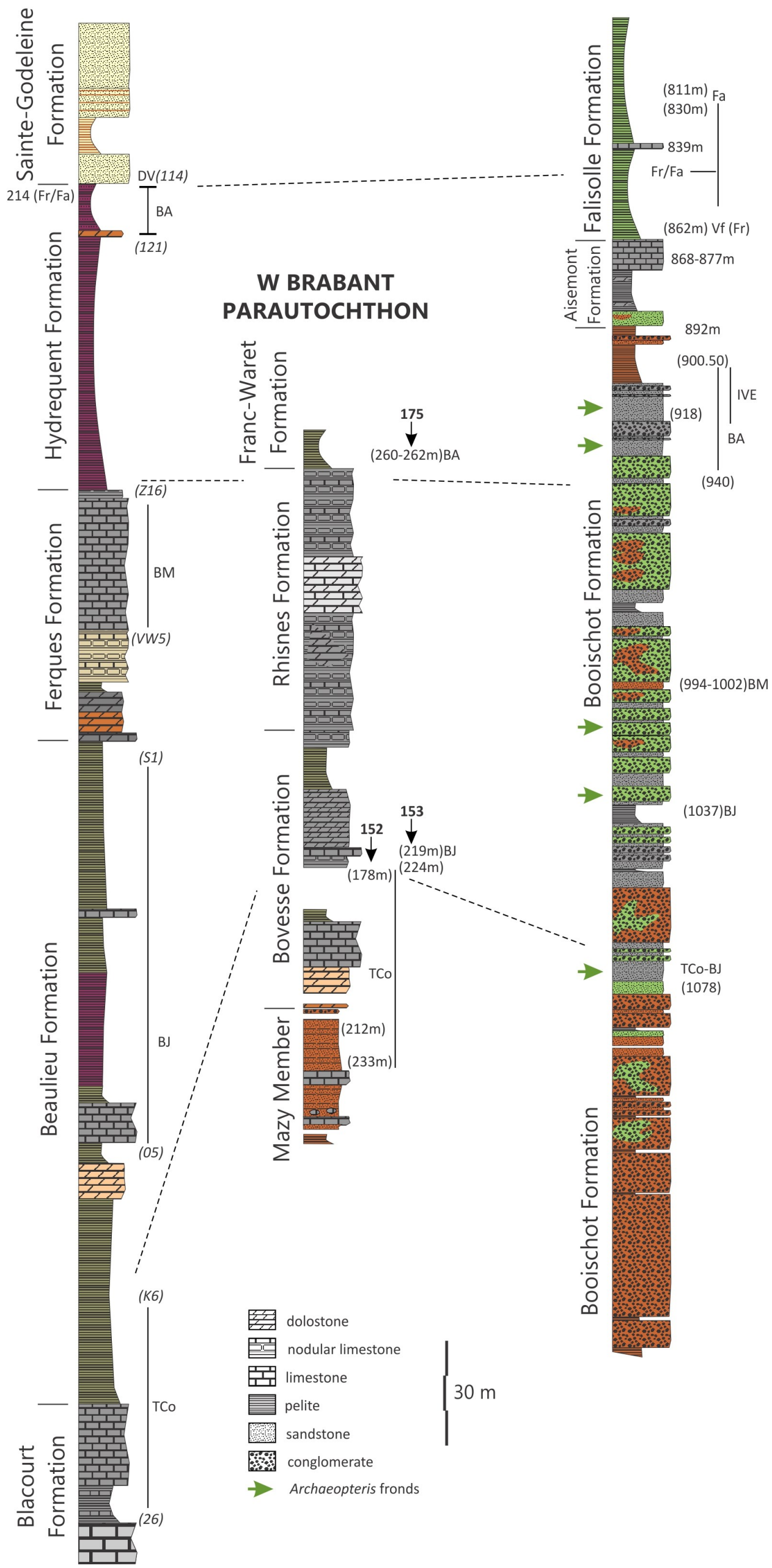

Figure 4. Formation names and lithology after Boulvain et al. (1999), Bultynck et al. (1991), Lagrou \& Coen-Aubert (2017), Mansy et al. (2007). Miospore Zones extensions in the Boulonnais between samples (x) located on Figure 1 (lithostratigraphy); in W Brabant, depth in boreholes (this paper); in Campine Basin, depth in Booischot Borehole, miospores after Streel (1965), Streel \& Loboziak (1987); acritarch data for Falisolle Formation after Vanguestaine et al. (1983). Green arrows locate after Legrand (1964) abundant fronds of Archaeopteris fimbriata versus $A$. macilenta. 
one third of the spore radius, expanding in front of the trilete rays. Ornaments are mainly composed, on the distal and equatorial surfaces, of coni reaching sometimes 2-3 $\mu \mathrm{m}$ high and $2 \mu \mathrm{m}$ wide. This taxon might well be part of a $S$. triangulatus sensu lato morphon yet to be defined (see also Allen, 1982).

Samarisporites sp. D (79) in Loboziak, Streel \& Vanguestaine 1983, plate 2: 2-3.

1988. Samarisporites sp. D, in Loboziak \& Streel 1988, plate 3: 14 .

Equatorial margin subtriangular. Ornament of coni (up to 2 $\mu \mathrm{m}$ high and wide) borne on irregular crests that are more or less fused in an imperfect reticulum (mesh 3-6 $\mu \mathrm{m}$ ). Ornamentation denser on polar area than on the zona which reaches sometimes to one half of the spore radius.

Samarisporites sp. E in Streel \& Loboziak 1987, plate 1: 10. 1965. Calyptosporites microspinosus Richardson 1962 in Streel 1965, plate II: 10.

1974. Samarisporites sp. aff. S. inusitatus Allen 1965 in Becker et al. 1974, plate 18: 7.

1981. Samarisporites triangulatus Allen 1965 in Loboziak \& Streel 1981, plate II: 3 .

1989. Samarisporites sp. E in Loboziak \& Streel 1989, plate IV: 9.

Non Samarisporites triangulatus Allen 1965 in Loboziak \& Streel 1981, plate II: 4-5.

Rounded central body and equatorial margin subtriangular. Ornament of small verrucae and sometimes coni (up to $2 \mu \mathrm{m}$ high and wide) borne on irregular crests to form a more or less fused imperfect reticulum (smaller mesh than in Samarisporites sp. D.). Compare with Samarisporites inusitatus Allen 1965 (see Breuer \& Steemans, 2013, fig. 40: B-C) which has an equatorial margin that is less triangular in shape and with rare spines on the verrucae.

Samarisporites triangulatus Allen 1965 in Loboziak \& Streel 1981, plate II: 4-5. = Cristatisporites deliquescens (Naumova) Arkhangelskaya in Obukhovskaya et al. 2000, plate $1: 1$, plate $4: 2$.

1981. Samarisporites ef triangulatus Allen 1965 in Loboziak \& Streel 1981, plate II: 6 .

1987. Samarisporites sp. F in Streel \& Loboziak 1987, plate1: 5?-6.

1991. Samarisporites sp. F in Loboziak et al. 1991, 2: 1-3.

Rounded central body with thin smooth equatorial zona showing small typical radial expansions.
This taxon might as well (see also S. sp. C) be part of a $S$. triangulatus sensu lato morphon yet to be defined (see also Allen, 1982).

Better definition of some taxa formerly attributed to Samarisporites triangulatus Allen 1965 (21) suggest that the range of this species in the BM and BA Zone should be revised. Two taxa (without identification number in Fig. 1) should obviously be added to the BM Zone: Samarisporites sp. E in Streel \& Loboziak (1987) and Cristatisporites deliquescens (Naumova) Arkhangelskaya, both occurring in the Ferques Formation from the Boulonnais.

\section{International correlations using Frasnian miospore zonations}

International correlations using Upper Devonian miospore zonations have been attempted between far-away basins (Streel et al., 2000b). For instance, comparison of the Boulonnais miospores with the Amazon Basin (Melo \& Loboziak, 2003), allowed, for the first time, to correlate, using microfossils, SW Gondwanaland and Laurussia.

At a smaller scale, Frasnian and Lower Famennian deposits, containing miospores, are widespread on the territory of the Pripyat Depression in SE Belarus and the Timan-Pechora Province in Russia. Biostratigraphy of these deposits is based also on conodonts in the Timan-Pechora.

A palaeophytogeographic reconstruction (Fig. 5) after Streel et al. (1990) shows, during Frasnian time, Eastern Europe centred on the equatorial belt and Western Europe in the tropical belt. It explains, to some extent, why different miospore zonations can be found in these regions (Streel et al., 2000a). Correlation charts between Western Europe and Eastern Europe have been tentatively published by Loboziak \& Streel (1981, 1988) but the most documented chart was published by Avkhimovitch et al. (1993) for the Middle and Upper Devonian and Obukhovskaya et al. (2000) for the Upper Frasnian and Famennian boundary deposits.

Correlations from the Late Givetian until the Mid Frasnian are shown on these charts to be obvious from the varcus to punctata conodont Zones (Obukhovskaya, 2000; Streel et al., 2000a; Tel'nova, 2008; Telnova et al., 2019) but less obvious from Middle Frasnian to the Lower Famennian within the Archaeoperisaccus ovalis-Verrucosisporites grumosus (OG), Cristatisporites deliquescens-Verrucosisporites evlanensis (DE) and Corbulispora vimineus-Geminospora vasjamica (VV) Assemblage-Acme Zones of Eastern Europe.

Subzone SB, in the lower part of the OG Zone, contains Cristatisporites deliquescens and is associated with the

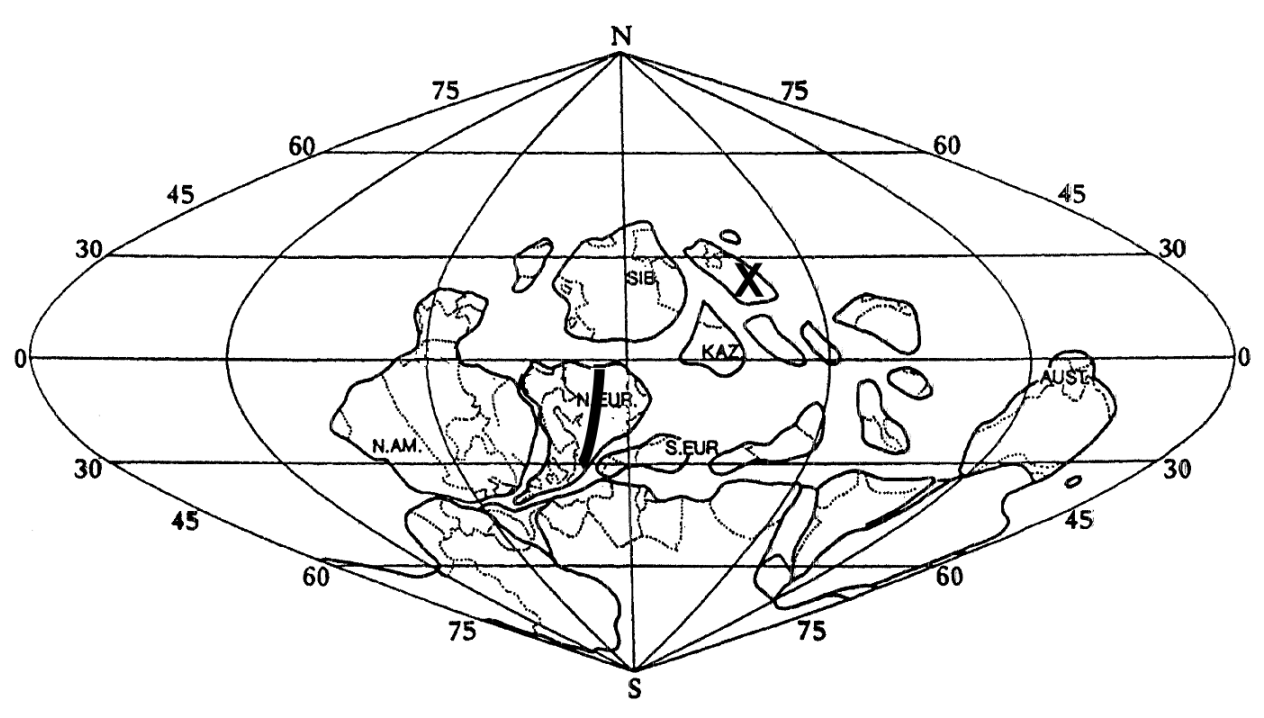

Figure 5. Global palaeogeography during Middle Devonian time after Heckel \& Witzke (1979). The map shows (black thick line) the tropical to equatorial transect of Western to Eastern Europe. Black X correspond to the locality studied in North-West China by Stachacz et al. (2020). 
Table 4. Correlation between late Frasnian miospore assemblages in Western and Eastern Europe.

Miospore zonation after Avkhimovitch et al. (1993). Conodont after the "standard" zonation of Ziegler \& Sandberg (1990). Substage limits based on SDS members votes (SDS Subcommission Devonian Stratigraphy Newsletter 22, 2007).

\begin{tabular}{lllll}
\hline \multicolumn{2}{c}{ Miospore zonations } & Conodont (Fig. 6) & Ages & FOB key species? \\
Western Europe & Eastern Europe & & & \\
\hline DV & VV & triangularis & Famennian & \\
BA plic-E & VV & triangularis & Famennian & Corbulispora vimineus (61) \\
BA grac & DE GS & linguiformis & Upper Frasnian & \\
BA pregrac & DE AS & rhenana & Upper Frasnian & Cymbosp. acanthaceus (57) \\
BM/BA ? & OG MR & rhenana & Upper Frasnian & Diducites mucronatus (74) \\
BM/BA ? & OG CVe & Early rhenana & Upper Frasnian & Grandispora gracilis (69) \\
BM & OG SB & hassi & Middle Frasnian & Cristatisporites deliquescens \\
\hline
\end{tabular}

conodont Upper Polygnathus asymmetricus and Ancyrognathus triangularis Zones i.e. more or less the hassi-jamieae level of the "standard" conodont zonation (Ziegler \& Sandberg, 1990). Subzone CVe, in the middle part of the OG Zone, contains Grandispora gracilis (69) and is associated to the conodont Lower gigas Zone or early rhenana level. Subzone MR in the upper part of the OG Zone, contains Diducites mucronatus (74) associated with the conodont gigas Zone.

Subzone AS, in the lower part of the DE Zone, contains Cymbosporites acanthaceus (57) and is associated with the conodont gigas Zone. Subzone GS, in the upper part of the DE Zone is referred to the conodont Uppermost gigas Zone or linguiformis level (see Fig. 6).

VV Zone shows the appearance of the first index species Corbulispora vimineus (61) and is correlated with conodonts of the Palmatolepis triangularis Zone.

Consequently it is proposed here (Table 4) that a correlation exists between part of the Verrucosisporites bulliferusLophozonotriletes media (BM) Oppel Zone, all of the

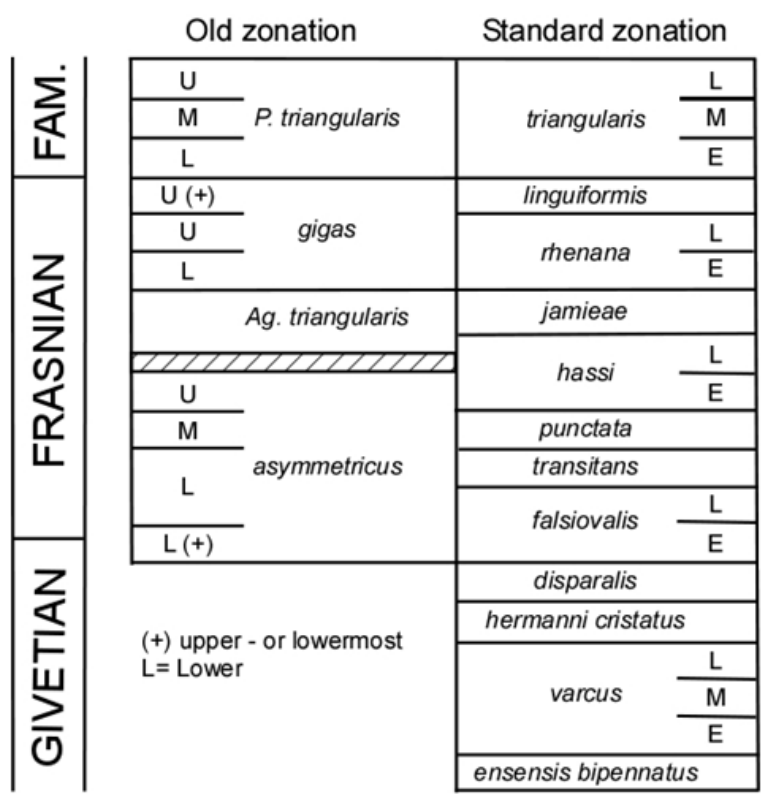

Figure 6. Conodont zonations after Klapper \& Ziegler (1979), Ziegler \& Sandberg (1990). Redrawn from Avkhimovitch et al. (1993, fig. 4).
Rugospora bricei-Cymbosporites acanthaceus (BA) Oppel Zone and part of the Knoxisporites dedaleus-Diducites versabilis (DV) Oppel Zone in Western Europe with the Archaeoperisaccus ovalis-Verrucosisporites grumosus (OG), Cristatisporites deliquescens-Verrucosisporites evlanensis (DE) and part of the Corbulispora vimineus-Geminospora vasjamica (VV) Assemblage-Acme Zones of Eastern Europe, covering the range from the conodont hassi Zone to the triangularis Zone.

The transition from the Rugospora bricei-Cymbosporites acanthaceus (BA) Oppel Zone and the Knoxisporites dedaleusDiducites versabilis (DV) Oppel Zone of Western Europe crossing the Frasnian-Famennian Boundary is tentatively recognised in the lowermost part of the Honggelelung Formation in the Bulongguoer section of the Junggar Basin in NW China (Stachacz et al., 2020). The Frasnian/Famennian Boundary is dated by Zircon-U-Pb (371.5 $\pm 0.9 \mathrm{Ma})$ immediately below the Honggelelung Formation, in the Zhulumute Formation in the same region (Zheng et al., 2020).

\section{Conclusions}

The correlation proposed on Table 4 at the transition BM/BA dated Upper Frasnian by the rhenana conodont Zone in Eastern Europe points to the inability in the Ferques and Hydrequent Formation succession between the La Parisienne Member (or Gris Member?) and the Dolomitic Beds (Brice et al., 1981) to trace the exact base of the Upper Frasnian in the Boulonnais. An initial examination at the many recorded ranges of taxa (Fig. 1) suggests, first of all, a sampling gap between these formations. Obviously, it suggests also a significant change in the vegetation cover occurring at that level which introduces the basal Famennian miospores characteristics of the DV Zone. Such a deep change in the vegetation cover might well have a climate origin (Streel et al., 2000a; Huang et al., 2018) corresponding more or less to the Lower Kellwasser Event (LKW) starting at the base of the Upper rhenana conodont Zone (Becker et al., 2016).

\section{Acknowledgements}

We would like to thank Alexandre Lambion (Department of Geology, Uliège) for technical assistance in preparing the samples from the Nieuwkerke-Noordhoek borehole. Marleen De Ceukelaire, Geo-collections manager of the Royal Belgian Institute of Natural Sciences is thanked for making the core available. We are grateful to the two reviewers, Prof. J. Marshall (Southampton) and Dr M. Coen-Aubert (Brussels) for their suggestions which greatly improved the manuscript. P.S. is a NFSR Senior Research Associate. 


\section{References}

Allen, K.C., 1965. Lower to Middle Devonian spores of North and Central Vestspitsbergen. Palaeontology, 8/4, 687-748.

Allen, K.C., 1982. Samarisporites triangulatus Allen 1965, an important Devonian miospore, and its synonymous species. Pollen et Spores, 24/1, 157-166.

Avkhimovitch, V.I., Tchibrikova, E.V., Obukhovskaya, T.G., Nazarenko, A.M., Umnova, V.T., Raskatova, L.G., Mantsurova, V.N., Loboziak, S. \& Streel, M., 1993. Middle and Upper Devonian miospore zonation of Eastern Europe. Bulletin des Centres de Recherches Exploration-Production Elf Aquitaine, 17, 79-147.

Becker, G., Bless, M.J.M., Streel, M. \& Thorez, J., 1974. Palynology and ostracode distribution in the Upper Devonian and basal Dinantian of Belgium and their dependence on sedimentary facies. Mededelingen Rijks Geologische Dienst, 25, 9-99.

Becker, R.T., Königshof, P. \& Brett, C.E., 2016. Devonian climate, sea level and evolutionary events: an introduction. In Becker, R.T., Königshof, P. \& Brett, C.E. (eds), Devonian climate, sea level and evolutionary events. Geological Society, London, Special Publications, 423, 1-10. https://doi.org/10.1144/SP423.15

Belanger, I., Delaby, S., Delcambre, B., Ghysel, P., Hennebert, M., Laloux, M., Marion, J.-M., Mottequin, B. \& Pingot, J.-L., 2012. Redéfinition des unités structurales du front varisque utilisées dans le cadre de la nouvelle Carte géologique de Wallonie (Belgique). Geologica Belgica, 15/3, 169-175.

Boulvain, F., Bultynck, P., Coen, M., Coen-Aubert, M., Lacroix, D., Laloux, M., Casier, J.G., Dejonghe, L., Dumoulin, V., Ghysel, P., Godefoid, J., Helsen, S., Mouravieff, N., Sartenaer, P. Tourneur, F. \& Vanguestaine, M., 1999. Les formations du Frasnien de la Belgique. Memoirs of the Geological Survey of Belgium, 44, 1-125.

Breuer, P. \& Steemans, P., 2013. Devonian spore assemblages from northwestern Gondwana: taxonomy and biostratigraphy. Special Paper in Palaeontology, 89, 1-163.

Brice, D., Bultynck, P., Deunff, J., Loboziak, S. \& Streel, M., 1979. Données biostratigraphiques nouvelles sur le Givétien et le Frasnien de Ferques (Boulonnais, France). Annales de la Société géologique du Nord, 98, 325-344.

Brice, D., Coen, M., Loboziak, S. \& Streel, M., 1981. Précisions biostratigraphiques relatives au Dévonien supérieur de Ferques (Boulonnais). Annales de la Société géologique du Nord, 100, 159166.

Bultynck, P., Coen-Aubert, M., Dejonghe, L., Godefroid, J., Hance, L., Lacroix, D., Préat, A., Stainier, P., Steemans, P., Streel, M. \& Tourneur, F., 1991. Les formations du Dévonien moyen de la Belgique. Mémoires pour servir à l'explication des cartes géologiques et minières de la Belgique, 30, 1-106.

Coen-Aubert, M., 2014. Revision of the Frasnian marine deposits from the Booischot borehole (Campine Basin, Belgium). Geologica Belgica, 17/3-4, 333-337.

Coen-Aubert, M., Groessens, E. \& Legrand, R., 1980. Les formations paléozoïques des sondages de Tournai et de Leuze. Bulletin de la Société belge de Géologie, 89/4, 271-275.

Dusar, M. \& Loy, W., 1986. The geology of the Upper Paleozoic aquifer in West-Flanders. Aardkundige Mededelingen, 3, 59-74.

Heckel, P.H. \& Witzke, B.J., 1979. Devonian world palaeogeography determined from distribution of carbonates and related lithic palaeoclimatic indicators. In House M.R., Scrutton C.T. \& Bassett, M.G. (eds), The Devonian System. Special Paper in Palaeontology, 23, 99-123.

Huang, C., Joachimski, M.M. \& Gong, Y., 2018. Did climate changes trigger the Late Devonian Kellwasser Crisis? Evidence from a highresolution conodont $\delta^{18} \mathrm{O}_{\mathrm{PO} 4}$ record from South China. Earth and Planetary Science Letters, 495, 174-184. https://doi.org/10.1016/ j.eps1.2018.05.016

Klapper, G. \& Ziegler, W., 1979. Devonian conodont biostratigraphy. Special Papers in Palaeontology, 23, 199-224.

Lagrou, D. \& Coen-Aubert, M., 2017. Update of the Devonian lithostratigraphic subdivision in the subsurface of the Campine
Basin (northern Belgium). Geologica Belgica, 20/1-2, 1-13. https:// doi.org/10.20341/gb.2016.017

Legrand, R., 1964. Coupe résumée du forage de Booischot (Province d'Anvers). Bulletin de la Société belge de Géologie, de Paléontologie et d'Hydrologie, 72, 407-409.

Legrand, R., 1981. Les "logs" des sondages de Tournai et de VieuxLeuze. Service géologique de Belgique, Professional Paper, 180, 2 p.

Loboziak, S. \& Streel, M., 1980. Miospores in Givetian to lower Frasnian sediments dated by conodonts from the Boulonnais, France. Review of Palaeobotany and Palynology, 29, 285-299. https://doi.org/10.1016/0034-6667(80)90065-2

Loboziak, S. \& Streel, M., 1981. Miospores in middle-upper Frasnian to Famennian sediments partly dated by conodonts (Boulonnais, France). Review of Palaeobotany and Palynology, 34/1, 49-66. https://doi.org/10.1016/0034-6667(81)90065-8

Loboziak, S. \& Streel, M., 1988. Synthèse palynostratigraphique de l'intervalle Givetien-Famennien du Boulonnais (France). In Brice, D. (ed.), Le Dévonien de Ferques, Bas-Boulonnais (N. France). Biostratigraphie du Paléozoique, 7, 71-77.

Loboziak, S. \& Streel, M., 1989. Middle-Upper Devonian miospores from the Ghadamis Basin (Tunisia-Libya): Systematics and stratigraphy. Review of Palaeobotany and Palynology, 58, 173-196. https://doi.org/10.1016/0034-6667(89)90084-5

Loboziak, S., Streel, M. \& Vanguestaine, M., 1983. Miospores et acritarches de la formation d'Hydrequent (Frasnien supérieur à Famennien inférieur, Boulonnais, France). Annales de la Société géologique de Belgique, 106, 173-183.

Loboziak, S., Streel, M., Caputo, M.V. \& Melo, J.H.G., 1991. Evidence of west European defined miospore zones in the uppermost Devonian and Lower Carboniferous of the Amazonas Basin (Brazil). Geobios, 24, 5-11. https://doi.org/10.1016/0016-6995(91) 80031-T

Mansy, J.-L., Guennoc, P., Robaszynski, F., Amédro, F., Auffret, J.-P., Vidier, J.-P., Lamarche, J., Lefèvre, D., Sommé, J., Brice, D., Mistiaen, B., Prud'homme, A., Rohart, J.-C. \& Vachard, D., 2007. Carte géologique de la France : notice explicative de la feuille de Marquise (5) à 1/50 000. $2^{\mathrm{e}}$ éd. BRGM édition, Orléans, $208 \mathrm{p}$.

Martin, F., 1993. Acritarchs: a review. Biological Review, 68, 475-538. https://doi.org/10.1111/j.1469-185X.1993.tb01241.x

Melo, J.H.G. \& Loboziak, S., 2003. Devonian-Early Carboniferous miospore biostratigraphy of the Amazon Basin, northern Brazil. Review of Palaeobotany and Palynology, 124, 131-202. https:// doi.org/10.1016/S0034-6667(02)00184-7

Naumova, S., 1953. Spore-pollen assemblages of the Upper Devonian of the Russian Platform and their stratigraphic significance. Transactions of the Institute of Geological Sciences, Academy of Science, USSR, 143/60, 1-204. [In Russian].

Obukhovskaya, T., 2000. Miospores of the Givetian-Frasnian boundary deposits in Belarus. Acta Palaeobotanica, 40/1, 17-23.

Obukhovskaya, T.G., Avkhimovitch, V.I., Streel, M. \& Loboziak, S., 2000. Miospores from the Frasnian-Famennian Boundary deposits in Eastern Europe (the Pripyat Depression, Belarus and the TimanPechora Province, Russia) and comparison with Western Europe (Northern France). Review of Palaeobotany and Palynology, 112/4, 229-246. https://doi.org/10.1016/S0034-6667(00)00045-2

Richardson, J.B. \& McGregor, D.C., 1986. Silurian and Devonian spore zones of the Old Red Sandstone continent and adjacent regions. Geological Survey of Canada, Bulletin, 364, 1-79. https:// doi.org/10.4095/120614

Stachacz, M., Kondas, M., Filipiak, P. \& Ma, X. 2020. Environment and age of the Upper Devonian-Carboniferous Zhulumute and Hongguleleng Formations (Junggar Basin, NW China): Ichnological and palynological aspects. Acta Geologica Sinica. https://doi.org/10.1111/1755-6724.14408

Streel, M., 1965. Etude palynologique du Dévonien du sondage de Booischot (Belgique). Bulletin de la Société belge de Géologie, de Paléontologie et d'Hydrologie, 73/2, 172-185. 
Streel, M., 2009. Upper Devonian miospore and conodont zone correlation in western Europe. In Königshof, P. (ed.), Devonian change: case studies in palaeogeography and palaeoecology. Geological Society, London, Special publications, 314, 163-176. https://doi.org/10.1144/SP314.9

Streel, M. \& Loboziak, S., 1987. Nouvelle datation par miospores du Givétien-Frasnien des sédiments non marins du sondage de Booischot (Bassin de Campine, Belgique). Bulletin de la Société belge de Géologie, 96, 99-106.

Streel, M., Higgs, K.T., Loboziak, S., Riegel, W. \& Steemans, P., 1987. Spore stratigraphy and correlation with faunas and floras in the type marine Devonian of the Ardenno-Rhenish regions. Review of Palaeobotany and Palynology, 50, 211-229. https:// doi.org/10.1016/0034-6667(87)90001-7

Streel, M., Fairon-Demaret, M. \& Loboziak, S., 1990. Givetian-Frasnian phytogeography of Euramerica and western Gondwana based on miospore distribution. In McKerrow, W.S. \& Scotese, C.R. (eds), Palaeozoic Palaeogeography and Biogeography. Geological Society, London, Memoirs, 12, 291-296. https://doi.org/10.1144/ GSL.MEM.1990.012.01.28

Streel, M., Caputo, M.V., Loboziak, S. \& Melo, J.H.G., 2000a. Late Frasnian-Famennian climates based on palynomorph analyses and the question of the Late Devonian glaciations. Earth-Science Reviews, 52/1, 121-173. https://doi.org/10.1016/S0012-8252(00) 00026-X

Streel, M., Loboziak, S., Steemans, P. \& Bultynck, P., 2000b. Devonian miospore stratigraphy and correlation with the global stratotype sections and points. In Bultynck, P. (ed.), Subcommission on Devonian Stratigraphy. Fossil groups important for boundary definition. Courier Forschungsinstitut Senckenberg, 220, 9-23.

Taugourdeau-Lantz, J., 1960. Sur la Microflore du Frasnien supérieur de Beaulieu (Boulonnais). Revue de Micropaléontologie, 3/3, 144-154.

Taugourdeau-Lantz, J., 1967a. Les spores du Frasnien du BasBoulonnais (France). Review of Palaeobotany and Palynology, 1/14, 131-139. https://doi.org/10.1016/0034-6667(67)90115-7

Taugourdeau-Lantz, J., 1967b. Spores nouvelles du Frasnian du BasBoulonnais (France). Revue de Micropaléontologie, 10/1, 48-60. https://doi.org/10.1016/0034-6667(67)90115-7

Taugourdeau-Lantz, J., 1971. Les spores du Frasnien d'une région privilégiée, le Boulonnais. Mémoires de la Société géologique de France, 114, 1-86.

Tel'nova, O.P., 2008. Palynological characterization of GivetianFrasnian deposits in the reference Borehole section 1Balneologicheskaya (Southern Timan). Stratigraphy and Geological Correlation, 16/2, 143-161. https://doi.org/10.1134/ S0869593808020044

Telnova, O., Soboleva, M. \& Sobolev, D., 2019. Upper Devonian Cristatisporites deliquescens Palynozone and its correlation (Timan -North Urals Region). Filodiritto Editore, Proceedings, 253-261. https://doi.org/10.26352/D924F5043

Tourneur, F., Babin, C., Bigey, F.P., Boulvain, F., Brice, D., CoenAubert, M., Dreesen, R., Dusar, M., Loboziak, S., Loy, W. \& Streel, M., 1989. Le Dévonien du sondage de Nieuwkerke (Flandre Occidentale, Belgique - extrémité occidentale du Synclinorium de Namur). Annales de la Société Géologique du Nord, 108, 85-112.

Vanguestaine, M., 1986. Late Devonian and Carboniferous acritarch stratigraphy and paleogeography. Annales de la Société géologique de Belgique, 109/1, 93-102.

Vanguestaine, M., Declairfayt, T., Rouhart, A. \& Smeesters, A., 1983. Zonation par Acritarches du Frasnien supérieur - Famennien inférieur dans les Bassins de Dinant, Namur, Herve et Campine (Dévonien supérieur de Belgique). Annales de la Société géologique de Belgique, 106, 121-171.

Zheng, D., Chang, S.-C., Algeo, T., Zhang, H., Wang, B., Wang, H., Wang, J., Feng, C. \& Xu, H., 2020. Age constraint for an earliest Famennian forest and its implications for Frasnian-Famennian boundary in West Junggar, Northwest China. Palaeogeography,
Palaeoclimatology, Palaeoecology, 552, 109749. https:// doi.org/10.1016/j.palaeo.2020.109749

Ziegler, W. \& Sandberg, C.A., 1990. The Late Devonian Standard Conodont Zonation. Courier Forschungsinstitut Senckenberg, 121, $1-115$.
Manuscript received 31.05.2020, accepted in revised form 11.12.2020, available online 20.05.2021. 
Appendix. Identification numbers of taxa recorded on Figure 1, sorted by taxa name.

Acinosporites lindlarensis Riegel 1968 (Richardson et al. 1993) $=1$

Aneurospora cf. heterodonta (Naumova) Streel $1972=$ Acinosporites lindlarensis Riegel 1968 (Richardson et al. 1993) = 1

Ancyrospora ancyrea var. brevispinosa Richardson $1962=14$

Acanthotriletes cf. horridus Hacquebard 1957 sensu Richardson $1965=10$

Ancyrospora ancyrea var. ancyrea Richardson $1962=13$

Ancyrospora angulata Tiwari \& Schaarschmidt 1975 = 37

Ancyrospora langii (Taugourdeau-Lantz) Allen $1965=31$

Ancyrospora loganii McGregor $1973=15$

Ancyrospora lysii (Taugourdeau-Lantz) Loboziak \& Streel 1981= 52

Ancyrospora simplex Guennel $1963=46$

Aneurospora goensis Streel $1964=$ Geminospora expansa (Naumova)

Gao in Obukhovskaya $2000=11$

Aneurospora greggsii (McGregor) Streel $1974=24$

Aneurospora sp. A in Loboziak, Streel \& Vanguestaine $1983=77$

Aneurospora sp. B in Loboziak, Streel \& Vanguestaine $1983=78$

Archaeozonotriletes variabilis (Naumova) Allen 1965=2

Auroraspora hyalina (Naumova) Streel 1974 = 62

Auroraspora macra Sullivan $1968=63$

Auroraspora macromanifesta (Hacquebard) Richardson $1960=16$

Auroraspora micromanifesta (Hacquebard) Richardson 1960 = 17

Auroraspora solisorta Hoffmeister, Staplin \& Malloy $1955=70$

Auroraspora sp. A in Loboziak \& Streel $1981=66$

Biornatispora reticulata Lele \& Streel $1969=25$

Brochotriletes $\mathrm{sp} .=3$

Bullatisporites aff. bullatus Allen $1965=18$

Chelinospora concinna Allen $1965=38$

Cirratriradites dissutus Allen $1965=19$

Cirratriradites jekhowskyi Taugourdeau-Lantz 1967b $=39$

Contagisporites optivus var. vorobjevensis (Chibrikova) Owens 1971 = 12

Convolutispora cf. subtilis Owens $1971=43$

Convolutispora disparilis Allen $1965=4$

Convolutispora paraverracuta McGregor $1964=5$

Convolutispora tegula Allen $1965=48$

Corbulispora sp. in Loboziak \& Streel $1981=$ C. viminea (Nekriata)

Obukhovskaya \& Nekriata in Obukhovskaya et al. $2000=61$

Corbulispora viminea (Nekriata) Obukhovskaya \& Nekriata in

Obukhovskaya et al. $2000=61$

Corystisporites multispinosus Richardson $1965=42$

Cymbosporites acanthaceus (Kedo) Obukhovskaya in Obukhovskaya et

al. $2000=57$

Cymbosporites cf. cyathus Allen $1965=20$

Cymbosporites sp. A in Loboziak \& Streel 1981 = 68

Cymbosporites sp. B in Loboziak \& Streel $1981=$ C. acanthaceus

(Kedo) Obukhovskaya in Obukhovskaya et al. $2000=57$

Cymbosporites sp. C in Loboziak, Streel \& Vanguestaine $1983=75$

Densosporites ssp. Loboziak \& Streel 1981 No records $=71$

Dibolisporites cf. gibberosus (Naumova) Richardson $1965=6$

Dibolisporites echinaceus (Eisenack) Richardson 1965 $=28$

Dibolisporites sp. cf. Lophotriletes atratus (Naumova) sensu Streel 1974= 41

Diducites mucronatus (Kedo) Van Veen 1981 = 74

Diducites plicabilis Van Veen $1981=64$

Diducites poljessicus (Kedo) Van Veen $1981=55$

Diducites versabilis (Kedo) Van Veen 1981 = 65

Emphanisporites spp. $=29$

Geminospora lemurata Balme $1962=40$

Geminospora expansa (Naumova) Gao in Obukhovskaya 2000 $=11$

Grandispora cf. tenuispinosa (Hacquebard) Playford 1971 in Streel $1974=53$

Grandispora douglastownense McGregor $1973=7$

Grandispora gracilis (Kedo) Streel 1974 = 69

Grandispora inculta Allen 1965 = 21

Grandispora sp. A in Loboziak \& Streel 1981 No records $=56$

Grandispora tomentosa Taugourdeau-Lantz 1967b $=32$

Grandispora velata (Eisenack) McGregor $1973=22$

Hystricosporites multifurcatus (Winslow) Mortimer \& Chaloner 1967 = 47
Hystricosporites spp. $=33$

Knoxisporites cf. hederatus (Ishenko) Playford $1963=60$

Knoxisporites dedaleus (Naumova) Streel $1977=59$

Lophozonotriletes media Taugourdeau-Lantz 1967b $=50$

Perotrilites ergatus Allen $1965=34$

Planisporites scaber Taugourdeau-Lantz 1967b $=49$

Pustulatisporites rugulatus (Taugourdeau-Lantz) Loboziak \&Streel $1981=51$

Retusotriletes planus Dolby \& Neves $1970=67$

Retusotriletes rugulatus Riegel 1973 = Scylaspora rugulata (Riegel)

Breuer et al. $2007=30$

Rhabdosporites langi (Eisenack) Richardson $1960=8$

Rhabdosporites parvulus Richardson $1965=35$

Rugospora bricei Loboziak \& Streel $1989=58$

Rugospora cf. flexuosa (Juschko) Streel 1974= R. bricei Loboziak \&

Streel $1989=58$

Samarisporites inaequus (McGregor) Owens $1971=23$

Samarisporites sp. A in Loboziak \& Streel 1981 = 54

?Samarisporites sp. B in Loboziak, Streel \& Vanguestaine $1983=73$

Samarisporites sp. C in Loboziak, Streel \& Vanguestaine $1983=76$

Samarisporites sp. D in Loboziak, Streel \& Vanguestaine $1983=79$

Samarisporites triangulatus Allen $1965=36$

Scylaspora rugulata (Riegel) Breuer et al. $2007=30$

Verruciretusispora pallida (McGregor) Owens $1971=9$

Verruciretusispora sp. A in Loboziak, Streel \& Vanguestaine $1983=72$

Verrucosisporites bulliferus Richardson \& McGregor $1986=45$

Verrucosisporites $c f$. grandis McGregor $1960=44$

Verrucosisporites cf. uncatus (Naumova) Richardson $1965=27$

Verrucosisporites premnus Richardson $1965=26$ 

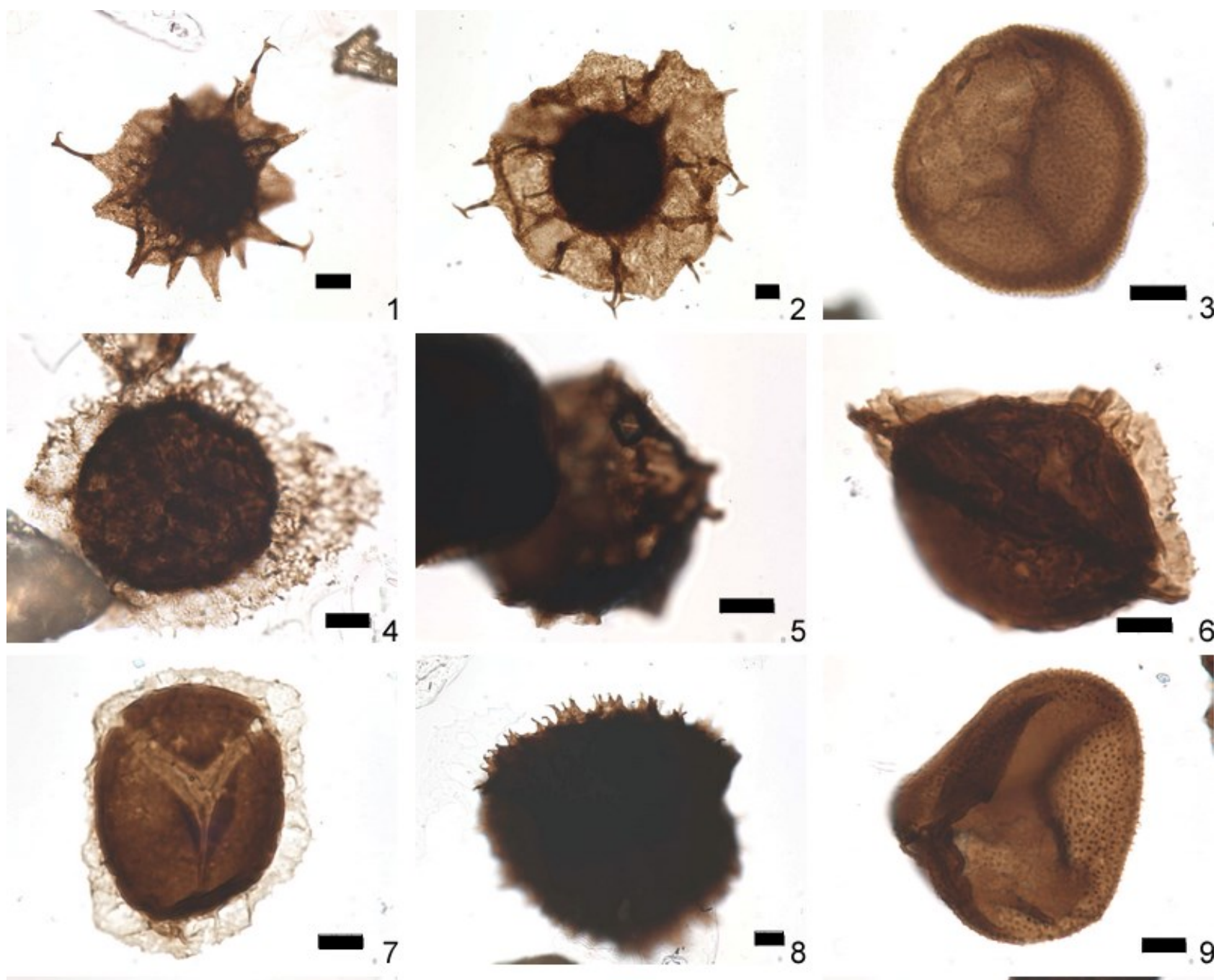

5
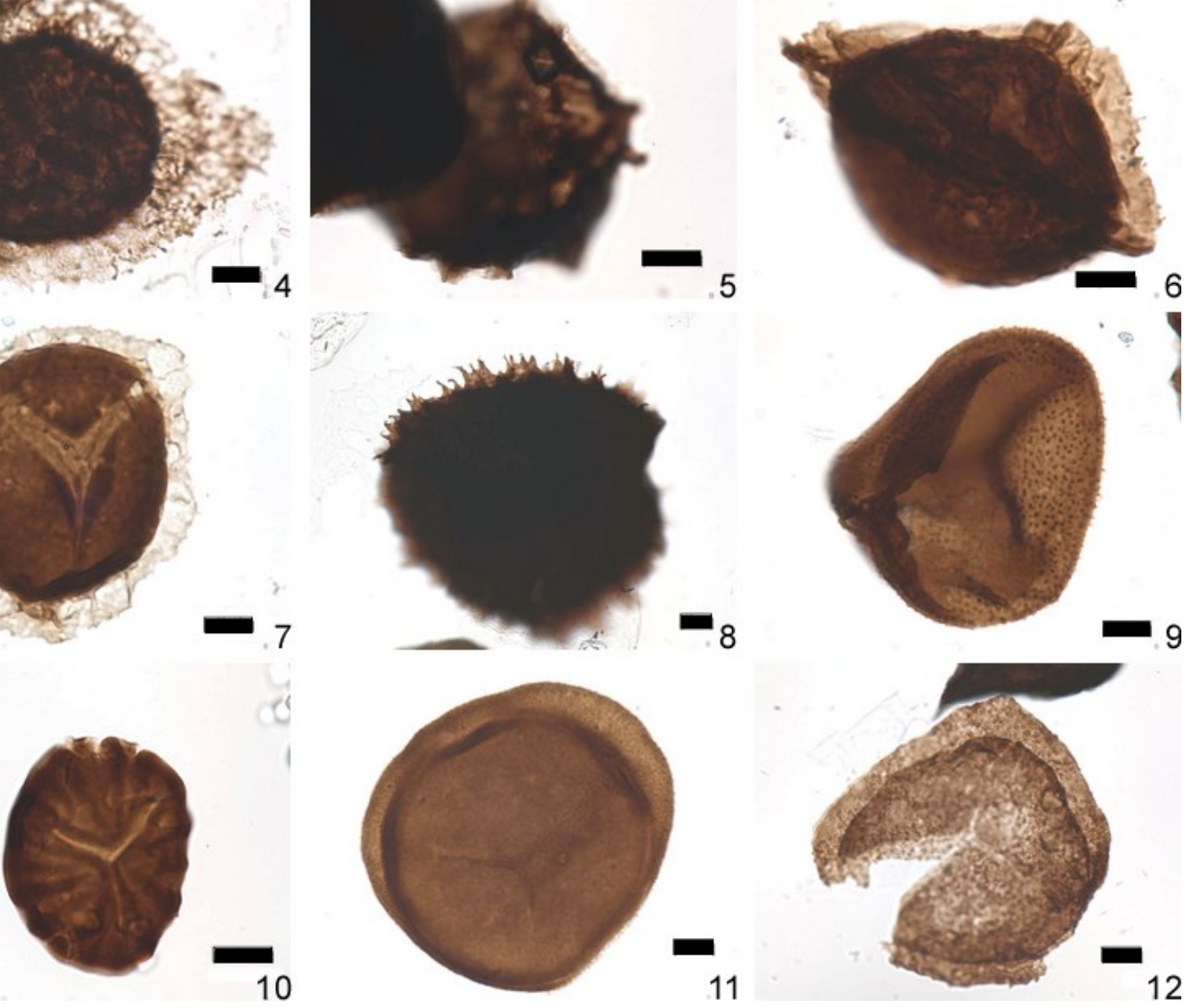

Plate 1a. Miospores recorded in the borehole Nieuwkerke-Noordhoek (95W153).

1, 2: Ancyrospora angulata (37) 1:223, 7, H50-3-4, 2:219,0, G45-2.

3: Aneurospora greggsii (24) 221, 5 L36-0.

4: Auroraspora aff. pseudocrista Ahmed 1980: 223,7, R40-1-4.

5: Chelinospora concinna (38) 219,0, N43-4.

6, 7: Cirratriradites jekhowskyi (39) 219,0, 6:M42-3. 7:T52-4.

8: Corystisporites multispinosus (42) 223, 7, F55-4.

9: Dibolisporites echinaceus (28) 219,0, R43-0.

10: Emphanisporites spp (29) 219,0, W41-4.

11, 12: Geminospora lemurata (40) 11:221,5, M4-,0. 12:223,7, H53-1-2.

Scale bar $=10 \mu \mathrm{m}$. 


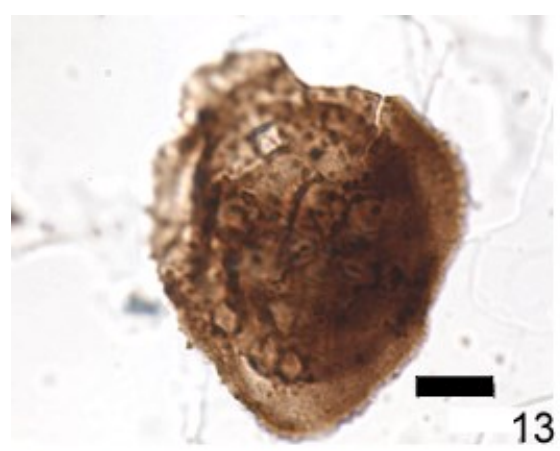

$\theta$

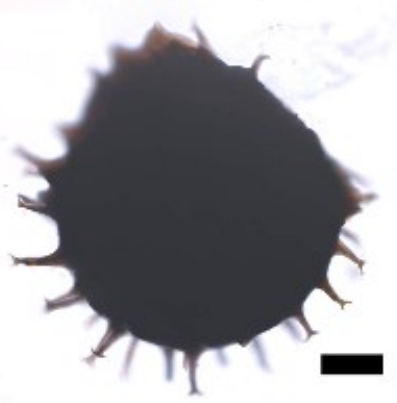

16

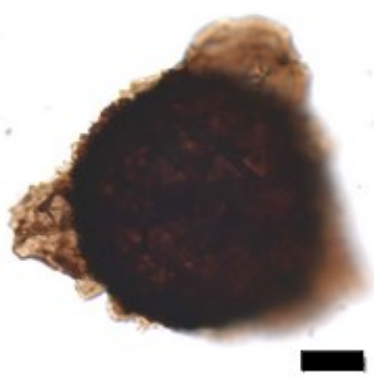

19

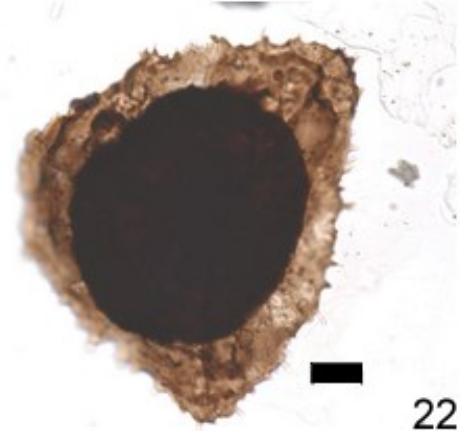

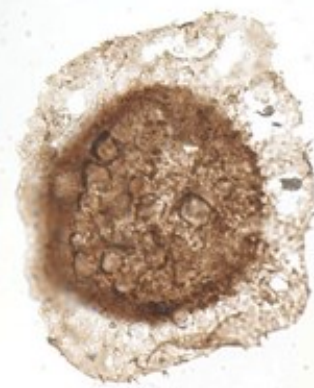

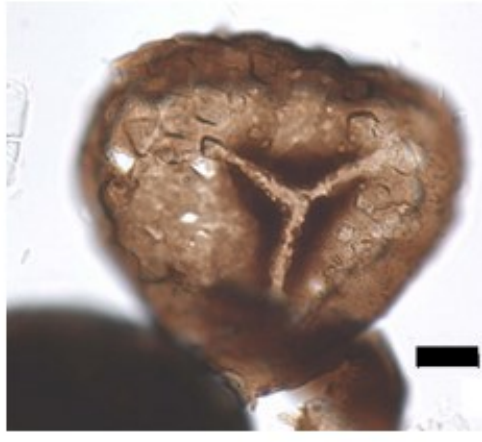

17

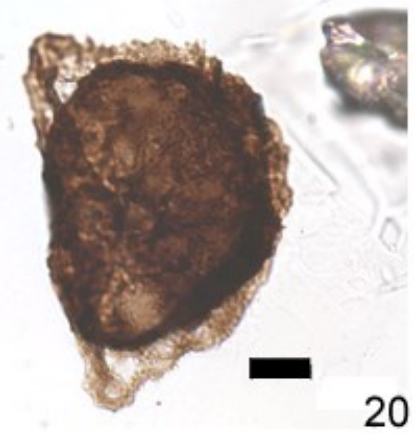

20

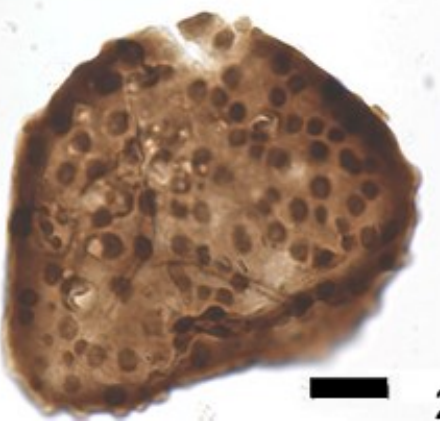

14

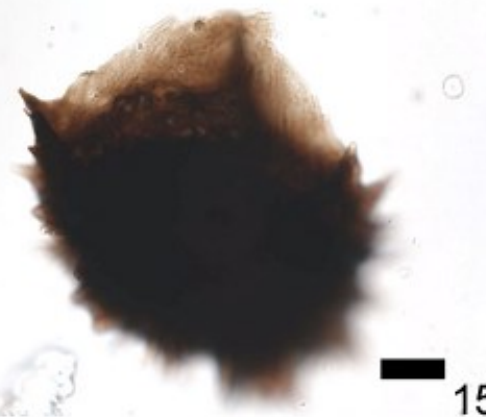

15

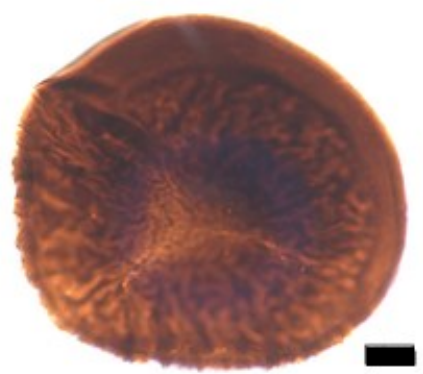

18
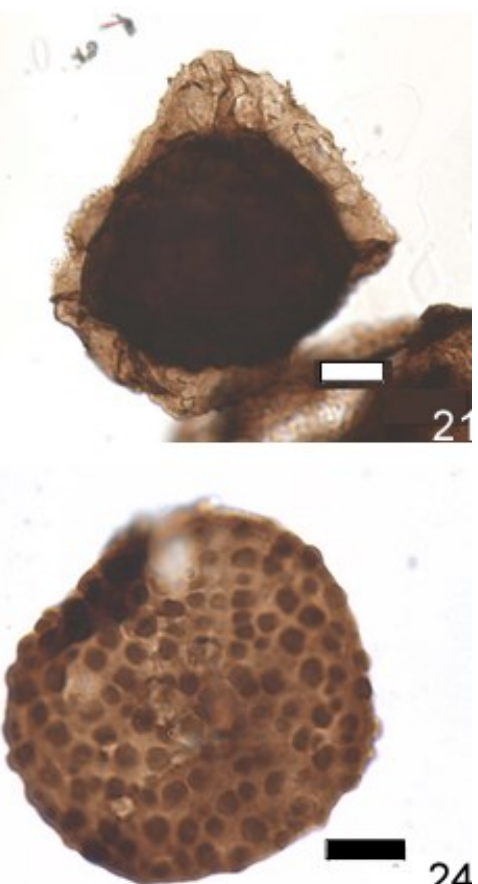

24

Plate 1b. Miospores recorded in the borehole Nieuwkerke-Noordhoek (95W153) (continued).

13: Grandispora inculta (21) 223,7. J38-3.

14: Grandispora velata (22) 223,7, G57-0.

15, 16: Hystricosporites spp (33) $15: 219,0$, L44-3, $16: 223,7$, H39-3.

17: Retusotriletes confossus (Rich.) Streel 1967, 223,7, F51-0.

18: Scylaspora rugulata (Riegel) Breuer et al. 2007 (30) 221,5, G33-0.

19, 20: Samarisporites triangulatus (36) 223,7, 19:L37-12,20:J35-4.

21, 22: Samarisporites sp. E, 223,7, 21:U37-0, 22:L38-50.

23, 24: Verrucosisporites bulliferus (45) 221,5, 23:G48-3, 24:T46-3.

Scale bar $=10 \mu \mathrm{m}$. 

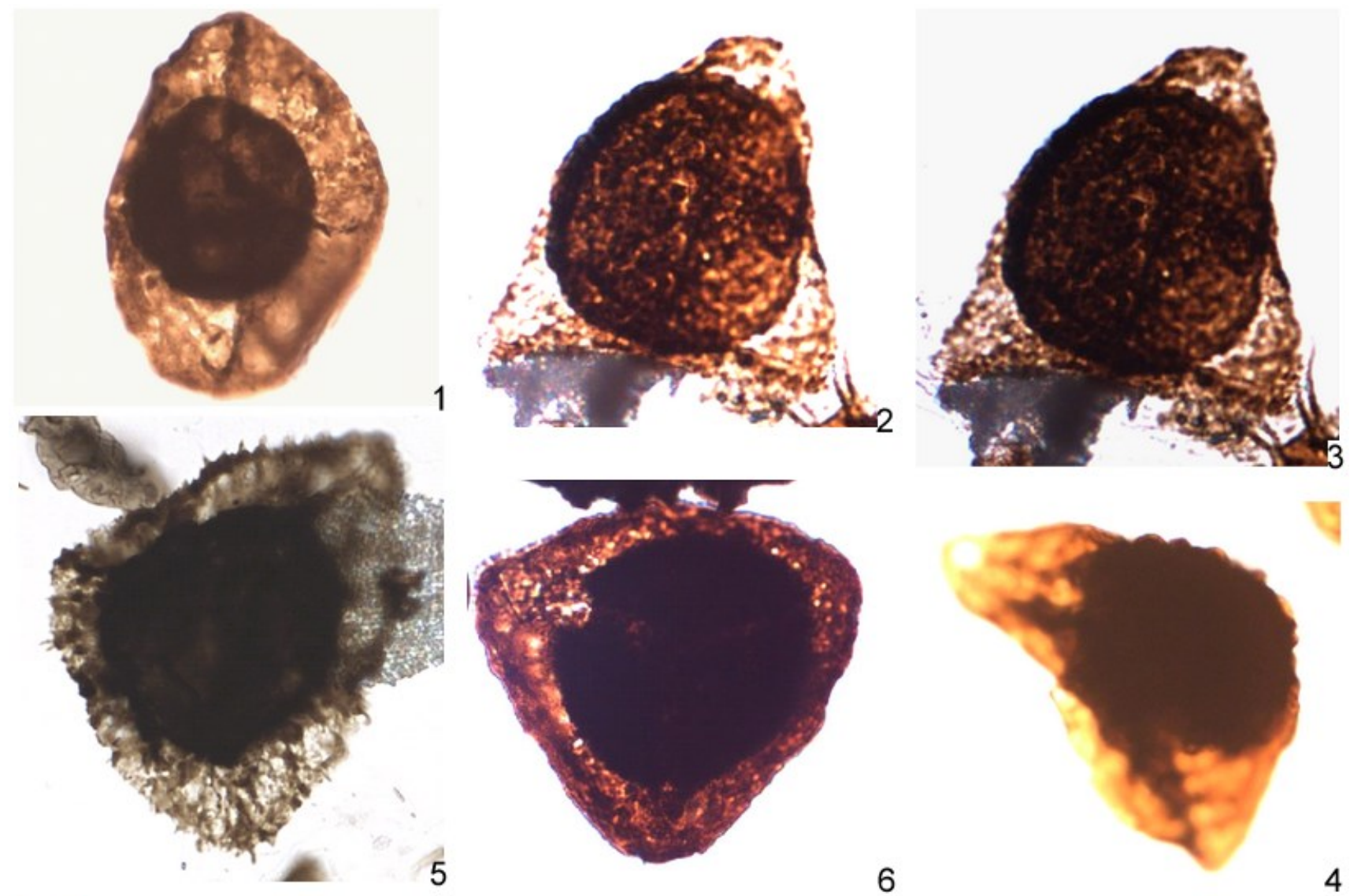

6
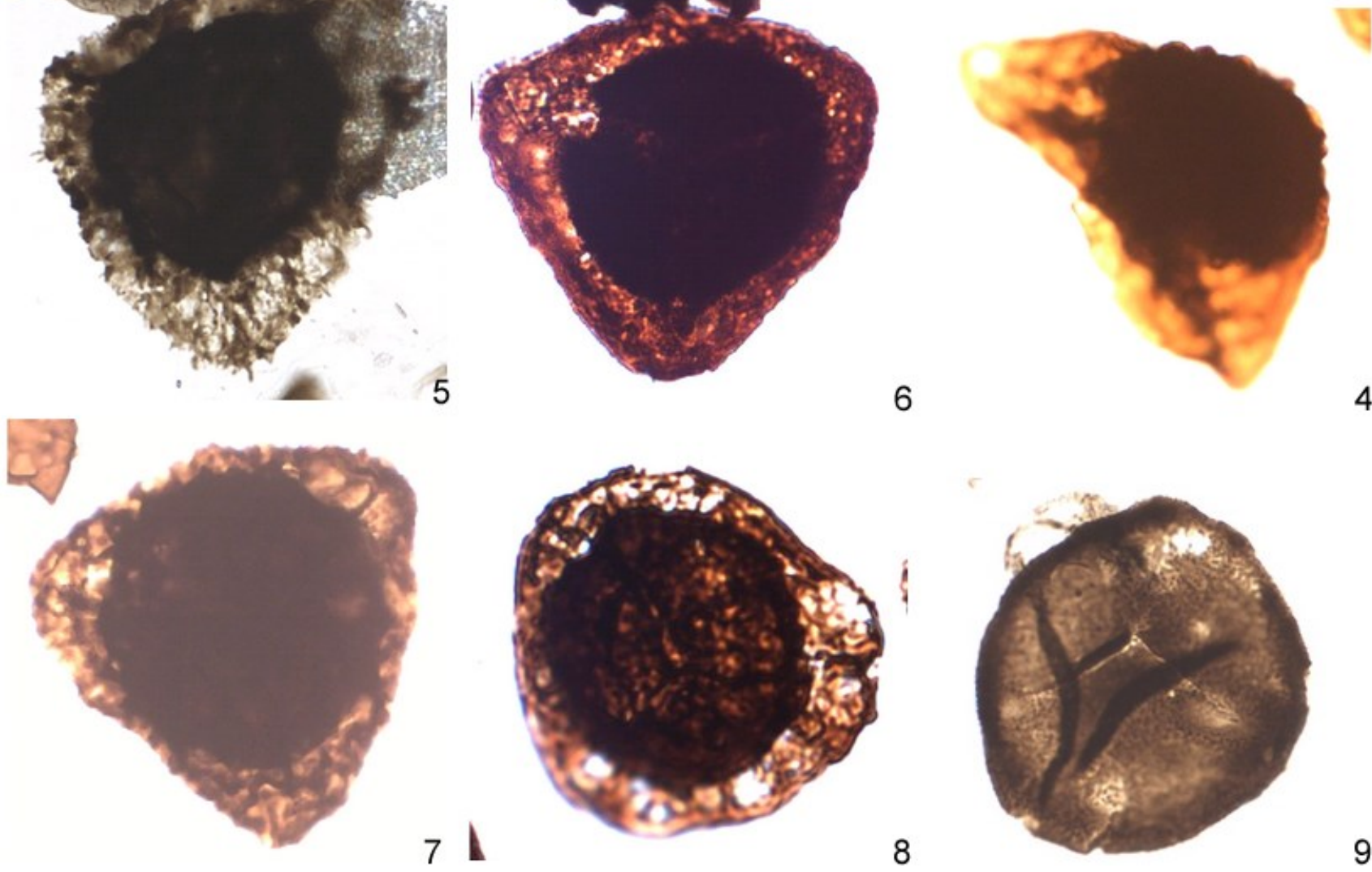

Plate 2a. Miospores recorded in the Heuvelland groundwater monitoring well (95W175).

1: aff. Archaeoperisaccus sp. H31-2.

2, 3, 4: Auroraspora pseudocrista Ahmed 1980 2,3: H41-2 4:048-3.

5, 6, 7: Samarisporites sp. D (79) in Loboziak, Streel \& Vanguestaine 1983, 5:M33-1, 6:O46-3, 7:E44-2.

8: cf. Teichertospora torquata (Higgs) McGregor \& Playford 1990, 8:O46-2.

9: Aneurospora greggsii (McGregor) Streel 1974 (24), W46-1.

All figures are at a magnification 700x unless otherwise stated. 

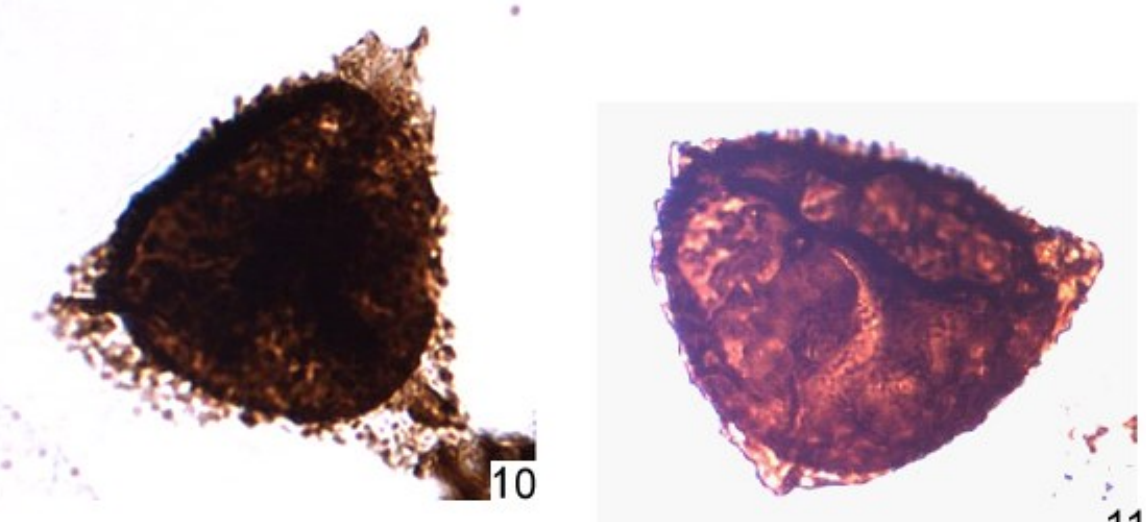

11
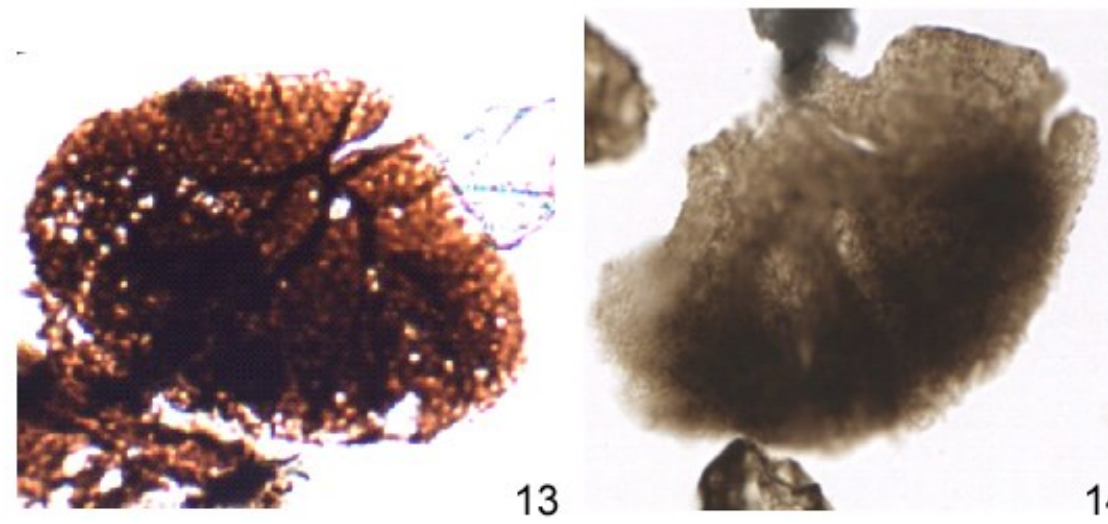

14

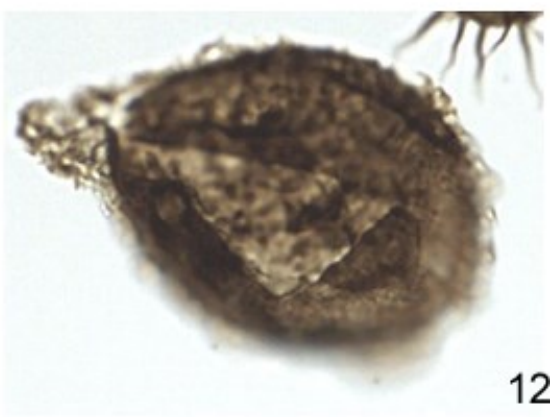

12

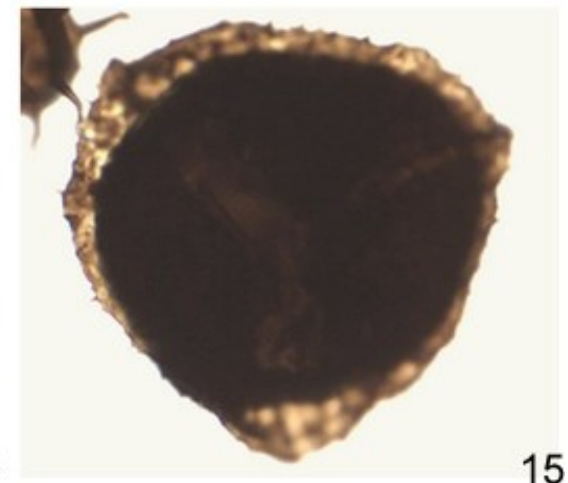

15

Plate 2b. Miospores recorded in the Heuvelland groundwater monitoring well (95W175) (continued).

10, 11: Samarisporites triangulatus Allen 1965 (36), 10:U48-4, 11:G44-4.

12: Diducites plicabilis (64), E47-3.

13, 14: Pavonisporites costulatus (Taugourdeau-Lantz) Taugourdeau-Lantz 1971, 13:N46-2, 14:V30; (x250).

15: Grandispora gracilis (69), O46-4.

All figures are at a magnification 700x unless otherwise stated. 